\title{
36. DATA REPORT: FORMATION MICROSCANNER IMAGERY OF LOWER CRETACEOUS AND JURASSIC SEDIMENTS FROM THE WESTERN PACIFIC (SITE 801) ${ }^{1}$
}

\author{
Alain J. Molinie ${ }^{2}$ and James G. Ogg ${ }^{3}$
}

\begin{abstract}
Ocean Drilling Program Leg 129 recovered Jurassic and Lower Cretaceous clayey radiolarite in Hole 801 B in the Pigafetta Basin of the western equatorial Pacific. Two runs of the Formation MicroScanner logging tool provided high-resolution downhole imagery of relative resistivity at this site. The Formation MicroScanner imagery was analyzed by using Schlumberger-processed gray-scale printouts and by using various enhancement methods on a Macintosh II color workstation. The processed images enabled continuous observation at approximately $1-\mathrm{cm}$ vertical resolution of variations in clay and radiolarian content, of discontinuities in sedimentation, of the degree of silicification, of nodularity of porcellanite and chert, of bedding thickness and spacing, of cyclic sedimentation exhibiting Milankovitch climatic periodicities, and of the dip of structures. The detailed Formation MicroScanner imagery was interpreted with the aid of other geophysical and dip-meter logs, and compared to the limited core recovery in order to compile a comprehensive stratigraphic column.

The lower $20 \mathrm{~m}$ of lower Callovian strata consist of a clay-rich series of slump structures and debris flows, with a possible breccia at the basal contact ( $467 \mathrm{mbsf}$ ) to the basaltic basement. Undisturbed but tilted upper Callovian beds of alternating radiolarite and claystone extend for less than $6 \mathrm{~m}$, then are terminated by an unconformity to Oxfordian-lower Tithonian interbedded chert and clayey radiolarite of lithologic Subunit IVb. Clay content and degree of silicification varies periodically within Subunit IVb. A mid-Tithonian bedded radiolarian chert, which may be a Pacific analog to "ribbon radiolarite," spans an 18-m interval (396-378 mbsf) at the base of lithologic Subunit IVa, and is overlain by a 5-m bed of claystone. A discontinuity in sedimentation is suspected at this Jurassic-Cretaceous boundary. The Berriasian-Valanginian consists of clayey radiolarite with periodic bands of chertification. A hardground, possibly silicified, is at $314 \mathrm{mbsf}$, overlain by $13 \mathrm{~m}$ of distal clay-rich volcaniclastic turbidites. Radiolarite sedimentation resumes for another $20 \mathrm{~m}$, then a second and major pulse of volcaniclastic turbidites begins at $281 \mathrm{mbsf}$.

The Formation MicroScanner stratigraphy was augmented with a synthetic plot of chert/clay ratio, as computed from cross-correlation of density and geochemical logs.
\end{abstract}

\section{INTRODUCTION}

Geophysical and geochemical logs provide an important supplement to cored sediments from drill holes, especially when core recovery is incomplete. Ocean Drilling Program (ODP) Leg 129 Site 801 encountered Callovian (upper Middle Jurassic) through Valanginian (Lower Cretaceous) clayey radiolarite, representing the oldest oceanic sediments recovered from the Pacific plate. However, core recovery within this important interval was generally less than $10 \%$, and commonly less than $2 \%$, of each drilled segment. A suite of logging tools was successfully deployed in Hole $801 \mathrm{~B}$, including two runs of the Formation MicroScanner (FMS), which provided highresolution imagery of microresistivity variations within the strata.

In this paper, we present details of the Jurassic and Lower Cretaceous stratigraphy of Site 801 as interpreted from the FMS imagery. As an Appendix, we present procedures to analyze FMS images on a Macintosh II color workstation using free-domain image software and a program "FMacS," which converts raw FMS data into 8-bit raster image files.

\section{FORMATION MICROSCANNER IMAGERY AND ANALYSIS}

\section{Formation MicroScanner Logging Tool}

The FMS tool creates high-resolution images of the borehole by measuring electrical resistivity across an array of small electrodes (Ekstrom et al., 1986; Pezard and Luthi, 1988; Bourke et al., 1989).

\footnotetext{
${ }^{1}$ Larson, R. L., Lancelot, Y., et al., 1992. Proc. ODP. Sci. Results, 129: College Station, TX (Ocean Drilling Program).

${ }^{2}$ Borehole Research Group, Lamont-Doherty Geological Observatory, Palisades, NY 10964, U.S.A.

${ }^{3}$ Department of Earth and Atmospheric Science, Purdue University, West Lafayette, IN 47907, U.S.A.
}

FMS imagery has been applied in the petroleum industry since 1986, but had been previously precluded from use by the Ocean Drilling Program (ODP) because of constraints imposed by the internal diameter (about $10 \mathrm{~cm}$ ) of the drill pipe. A modified sensor was consequently developed by Schlumberger for ODP and first deployed during Leg 126 in the western Pacific (Pezard et al., 1990).

The ODP FMS has four orthogonal pads containing 16 padmounted button electrodes which are pressed against the borehole (Fig. 1). The resolution of the ODP FMS images is improved by utilizing a smaller size of the electrode arrays than is common for the commercial FMS tool. The FMS records an array of current intensity or conductance measurements every $0.25 \mathrm{~cm}$ and has a vertical resolution of approximately $1 \mathrm{~cm}$. In contrast, typical conventional downhole measurements are sampled only every $15 \mathrm{~cm}$ and generally have a resolution of approximately $60 \mathrm{~cm}$; thus the sampling rate and resolution of the FMS is 60 times finer than for most other logging devices. This fine-scale resolution allows detailed study of subsurface structures and bedding characteristics.

The electrode currents probe the conductivity to a depth of a few centimeters into the borehole wall and respond to variations in electrolytic conduction or in cation exchange on the surfaces of clays and other conductive minerals (Bourke et al., 1989). The conductivity traces are presented as microresistivity, although the FMS does not provide a direct quantitative value of formation resistivity. Variations on these resistivity images reflect changing physical and chemical properties of the rock, such as porosity, mineralogy, cementation, and grain size, and of the interstitial fluid.

The four orthogonal sets of 16 adjacent traces are coded into either a gray-scale or a color image. In gray-scale images of this log of relative resistivity, white represents the most resistive values and black the least resistive ones. Magnetometers in the FMS tool string enable orientation of the set of images relative to north magnetic field, thereby enabling relative alignment of multiple traces made during separate runs and the determination of the orientation of dips and 


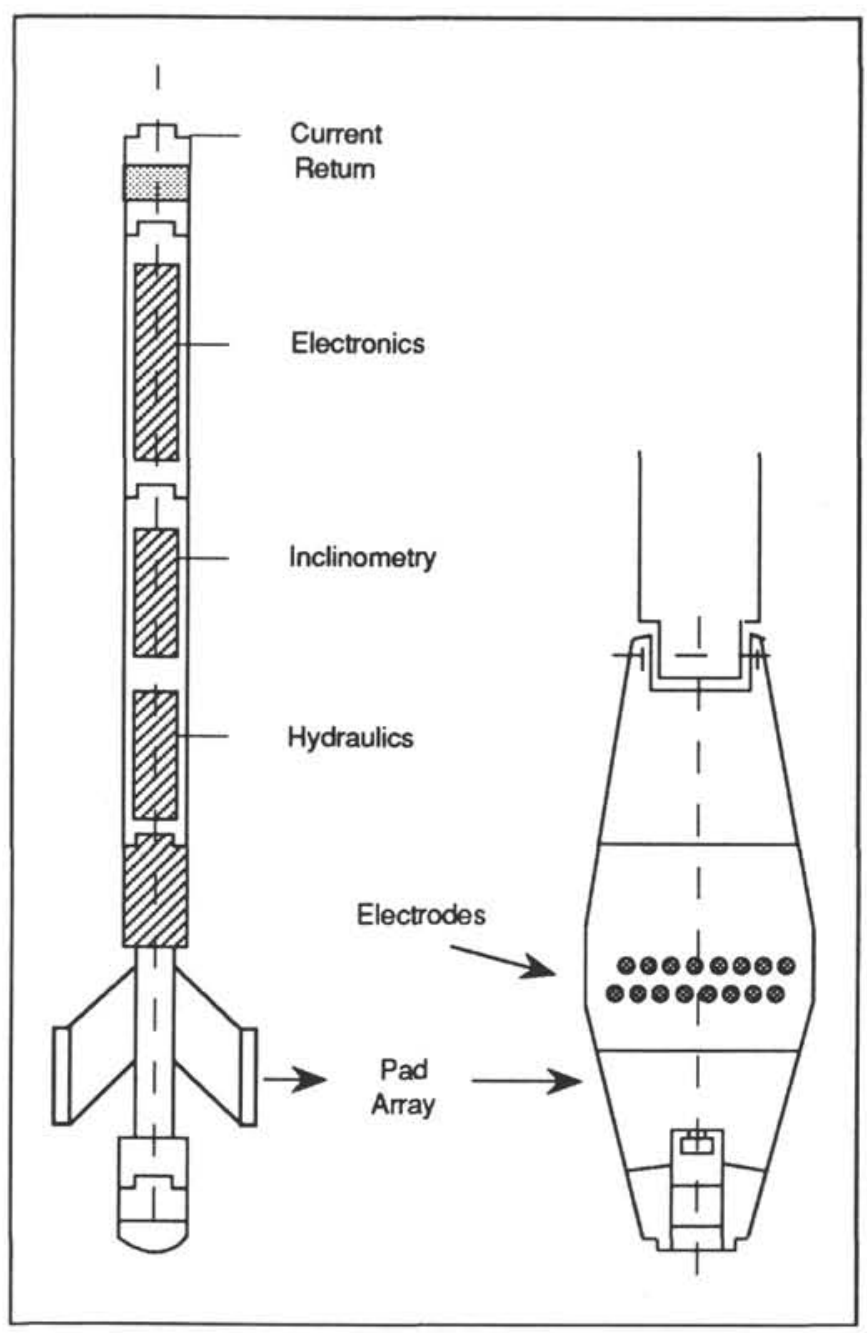

Figure 1. FMS resistivity logging tool. Four pads, each containing a grid of electrodes spaced at approximately $2.5-\mathrm{mm}$ intervals, record a continuous record of resistivity of the borehole walls. Additional instruments in the FMS tool string are an inclinometer and magnetometer to measure orientation of the traces, an accelerometer to convert the time record to a depth record of microresistivity, and a dipmeter array to measure structural attitudes. The tool string is about $6 \mathrm{~m}$ long. Sketch modified from Pezard et al. (1990).

sedimentary structures. A single run of the ODP FMS provides approximately $25 \%$ coverage of the borehole circumference. Two runs were made in Hole $801 \mathrm{~B}$ to enable a maximum of $50 \%$ coverage of the borehole where traces did not overlap.

Calibers on the FMS tool provide precise measurements of borehole diameter in two orthogonal directions. The tool string also includes a 3-axis accelerometer for recording variations in vertical speed and allows recognition of the exact position of the tool. This speed correction procedure is very important in ODP logging operations since the sampling intervals are disturbed by the heave effect of ocean surface waves on the wireline.

The FMS measurements undergo a series of processing steps which adjust the traces for irregular tool movements, fluctuating operating voltages and response of individual electrodes. The traces are then converted into enhanced images of the borehole (see Appendix). The desired type of interpretation influences the window dimensions over which resistivity images are normalized and the techniques of enhancement. The examples of FMS images reproduced in the figures in our report have been "static mode" processed over a $36-\mathrm{m}$ window, implying that the 16 shades of gray have been linearly normalized between the highest value of resistivity (white) to the lowest value (black) occurring within that interval. Within this window, a particular shade of gray corresponds to the same relative resistivity, but that resistivity level may be represented by a different gray shade in the adjacent window. We also used HILITE images, in which the entire gray scale is nonlinearly applied within a sliding $1-\mathrm{m}$ window. These HILITE images enhance visibility of bedding features and details of sedimentary structures.

Interpretations of sedimentological features from FMS images have varying degrees of reliability (Bourke et al., 1989; Harker et al., 1990). Stratigraphic contacts, bedding thicknesses and dips, slumps, cross bedding, fractures, and rock textures, such as conglomerates, can generally be unambiguously interpreted directly on the FMS imagery. Other downhole logs, such as natural gamma ray, resistivity, porosity, and geochemical logs, are required for calibration of general compositional and textural trends. However, as noted previously, such logs do not provide the resolution of the FMS; therefore, interpretation of fine-scale compositional contrasts, diagenetic variations, and other details noted on the images requires calibration with core data.

\section{Formation MicroScanner Response to Lithologies at Site 801}

Jurassic through Lower Cretaceous facies of Site 801 extends $150 \mathrm{~m}$ and consists entirely of radiolarite with variable amounts of clay enrichment and degrees of silicification. Carbonate was not indicated by core recovery or by geochemical logs from the top of the oceanic basalt to the base of the mid-Cretaceous volcaniclastic turbidites, and no evidence of clastic sediments or of volcanic ash beds was noted in the cores (Shipboard Scientific Party, 1990). The meager core recovery does not preclude the presence of lithologies other than radiolarite and claystone which may have been preferentially not recovered in this interval. However, based upon the available core and geochemical log evidence, we consider this facies to be predominantly a mixture of clay and radiolarian tests with variable degrees of silicification. The majority of our interpretations of FMS imagery of Hole 801B is based upon the assumption that the facies consist only of siliceous and clay-rich beds.

In this radiolarite facies of Hole $801 \mathrm{~B}$, the FMS traces of relative resistivity provide a powerful tool for detecting fine-scale changes in porosity. Low-resistivity zones, displayed as darker regions on the processed images, would be generated either by intervals having a greater content of clay, or by intervals of more poorly consolidated and porous clayey radiolarite. High-resistivity zones, displayed as lighter to white-colored regions on the images, would be generated by partially to completely silicified beds, or by other less porous lithologies. Therefore, the FMS images are interpreted to mainly be a recording of porosity variations caused by the degree of silicification. In turn, these variations in silicification are mainly reflections of the different proportions of clay to siliceous-radiolarians within the original sediment (Ogg et al., this volume).

Below approximately 467 meters below seafloor (mbsf) in Hole $801 \mathrm{~B}$ is a zone of relatively low resistivity corresponding to recovery of basalt flows and sills interbedded with chert (Shipboard Scientific Party, 1990; Ogg et al., this volume). Above approximately 314 mbsf, the recovered core lithologies consist primarily of turbidites of volcaniclastics interbedded with radiolarite. The presence of these nonradiolarite lithologies, coupled with the low core recovery for calibration, imply that interpretations of lithologic variations from the FMS imagery in these two intervals may be ambiguous.

\section{Interpretation Procedure}

Three forms of processing of the relative resistivity imagery from the FMS were examined (see Appendix for details):

1. Static-processed black-and-white hard copy from Schlumberger which is contrast-adjusted for individual 36-m sections. The 
relative resistivity of different beds within this 36-m interval can be compared, but subtle resistivity changes are obscured. This form of processing is the most useful to identify long-period facies changes. Preliminary versions of these processed logs are included as a microfilm supplement to the Leg 129 Initial Reports volume (Lancelot, Larson, et al., 1990).

2. HILITE-processed black-and-white hard copy from Schlumberger that employed a moving-window image enhancement to accentuate small-scale features. Contrast is continuously adjusted to reveal the subtle resistivity changes. However, this processing removes any trends or facies contrasts separated by wider than about $2 \mathrm{~m}$.

3. Macintosh color-graphics display of the appropriate 9-m section using a variety of image enhancement techniques. The software package is described in the Appendix. Color-coding, zoom, spectral analysis, and calibers aid in interpretation of sedimentary features.

As we examined each interval, the corresponding visual descriptions and photographs of the appropriate core segments were compared to features observed in the processed FMS images. Most cores were drilled at $4.5-\mathrm{m}$ intervals, but generally recovered only a few blocks. In general, zones of silica enrichment as indicated by the $\mathrm{Si}$ geochemical log and gamma ray log yielded the lowest amount of core recovery. The recovered sediments from all intervals commonly displayed rhythmic patterns of bedding or diagenetic silicification; therefore, it was generally not possible to make unambiguous correlations of the core pieces to the FMS images. In particular, pieces at the tops of some cores appeared to have been displaced downhole during the preceding core-barrow latching procedure. Nevertheless, the core recovery did enable confidence in interpreting lithologic features, such as composition, irregularly dipping beds, nodular bedding, chert-rich zones, turbidites, and interbasalt sediments.

In addition, we compared the large-scale variations seen in the FMS images to other logs of geochemical and physical properties, especially the $\mathrm{Si}$ and $\mathrm{Al}$ curves and gamma ray logs, as proxies of silica/clay ratio (Shipboard Scientific Party, 1990, and summarized in Molinie and Ogg, this volume). The depth offset of these logs and the FMS tool were intercalibrated using distinct high-amplitude features, such as the basalt-sediment interface and the well-cemented interval at 313-314 mbsf immediately below the lowest volcaniclastic pulse. It should be noted that both the preliminary and archive versions of the FMS images, including the microfilmed reproductions in the Initial Reports (Lancelot, Larson, et al., 1990), require the addition of $8 \mathrm{~m}$ to the printed shipboard depth scale due to a revision in the sediment-water interface depth made at the Leg 129 post-cruise meeting. For this report, all cited depths in meters below seafloor correspond to the FMS records incorporating this correction.

The combination of the three forms of processed FMS imagery and simultaneous reference to cored material and other logging runs enabled identification and interpretation of both large-scale facies trends and small-scale bedding features.

In the following sections, the FMS stratigraphy of patterns and trends in relative resistivity and the corresponding lithologies recovered in cores are summarized and interpreted (Fig. 2). Descriptions of the resistivity response and associated lithologic interpretations are grouped following the shipboard lithologic units and divided into subunits according to major differences in FMS image character. Discontinuities in the character of the imaged microresistivity were assumed to represent changes in sedimentary structures or lithology. Features noted as "spots" have distinct boundaries caused by resistivity contrasts to the matrix, whereas "mottles" have diffuse boundaries. FMS images are summarized in terms of relative resistivity, with greater resistivities represented by lighter colors in the black-and-white figures. The descriptions are summarized according to zones of common FMS image appearance and by the corresponding cored intervals.

\section{STRATIGRAPHY OF HOLE 801B FROM FORMATION MICROSCANNER IMAGERY}

\author{
Basaltic Basement (Upper Bathonian-Lower Callovian)
}

Core $129-801 B-38 R(466.1-470.1 \mathrm{mbsf})$

Basalt with Minor Chert

$469.8-470.0$ mbsf: Zone of very high relative resistivity with discontinuous bands of narrow ultra-high-resistive material.

468.3-469.8 mbsf: Ultra-high-resistivity zone, therefore appearing as nearly white-colored in the FMS imagery, with speckled appearance. Core recovery indicates this is probably a basalt flow. Thin subhorizontal features of low resistivity are interpreted as fractures. Slight downward decrease in relative resistivity to underlying unit.

467.0-468.3 mbsf: Poor FMS imagery, but appears to have lower relative resistivity than the underlying interval.

466.1-467.0 mbsf: Mottled to spotted appearance by less resistive material within an overall high resistivity matrix. Average relative resistivity decreases upward. We consider this interval to represent the basalt-to-sediment contact zone.

General interpretation: Basalt/sediment contact is between 466 and 467 mbsf. Underlying basalt contains subhorizontal fractures. The upper mottled and spotted interval could be a basaltic breccia overlying the basalt flow.

\section{Lower Portion of Lithologic Unit V (Callovian): Subunit VB}

\section{Core $129-801 B-37 R(461.5-466.1 \mathrm{mbsf})$}

\section{Pieces of Brittle-Fractured Chert above Uppermost Basalt}

463.1-466.1 mbsf: Low-resistivity matrix surrounding subrounded spots of very high resistivity. These resistive spots are bordered by halos of intermediate resistivity and comprise $30 \%$ of the interval. No sedimentary bedding is observed. This 3 -m-thick zone of relatively low resistivity is probably a clay-rich interval.

460.5-463.1 mbsf: Relatively high-resistivity zone with internal mottling by greater resistivity at $5-\mathrm{cm}$ scale; no banding observed. A peak in relative resistivity is at $461.8 \mathrm{mbsf}$. The interval 460.8-461.8 mbsf has an abundance of the most distinct spots of high-resistivity material.

General interpretation: The general characteristic of high-resistivity spots within a less resistive matrix is consistent with the appearance of a conglomerate or breccia in FMS images (e.g., Serra, 1989; Bourke et al., 1989). We interpret these beds to be either redeposited breccias composed of clasts of chert and/or basalt within a partially silicified clay-rich matrix or the result of in-situ brecciation. The few fragments of brittle-fractured chert of the core recovery were interpreted to be products of crackle brecciation of a soft sediment followed by differential silicification (Shipboard Scientific Party, 1990). The higher degrees of general silicification (greater resistivity) closer to the basaltic basement could represent alteration associated with silica-rich fluids from the basalt, such as was inferred for the silicification of interbasalt sediments and hydrothermal deposits (Shipboard Scientific Party, 1990).

\section{Core 129-801B-36R (456.9-461.5 mbsf)}

\section{No Recovery}

456.0-460.5 mbsf: Large mottles at the $50-\mathrm{cm}$ scale of higher resistivity within a less resistive matrix. These mottles have finer internal mottling. No sedimentary bedding was observed. The average resistivity is decreasing upward, suggesting an upward decrease in silicification. 


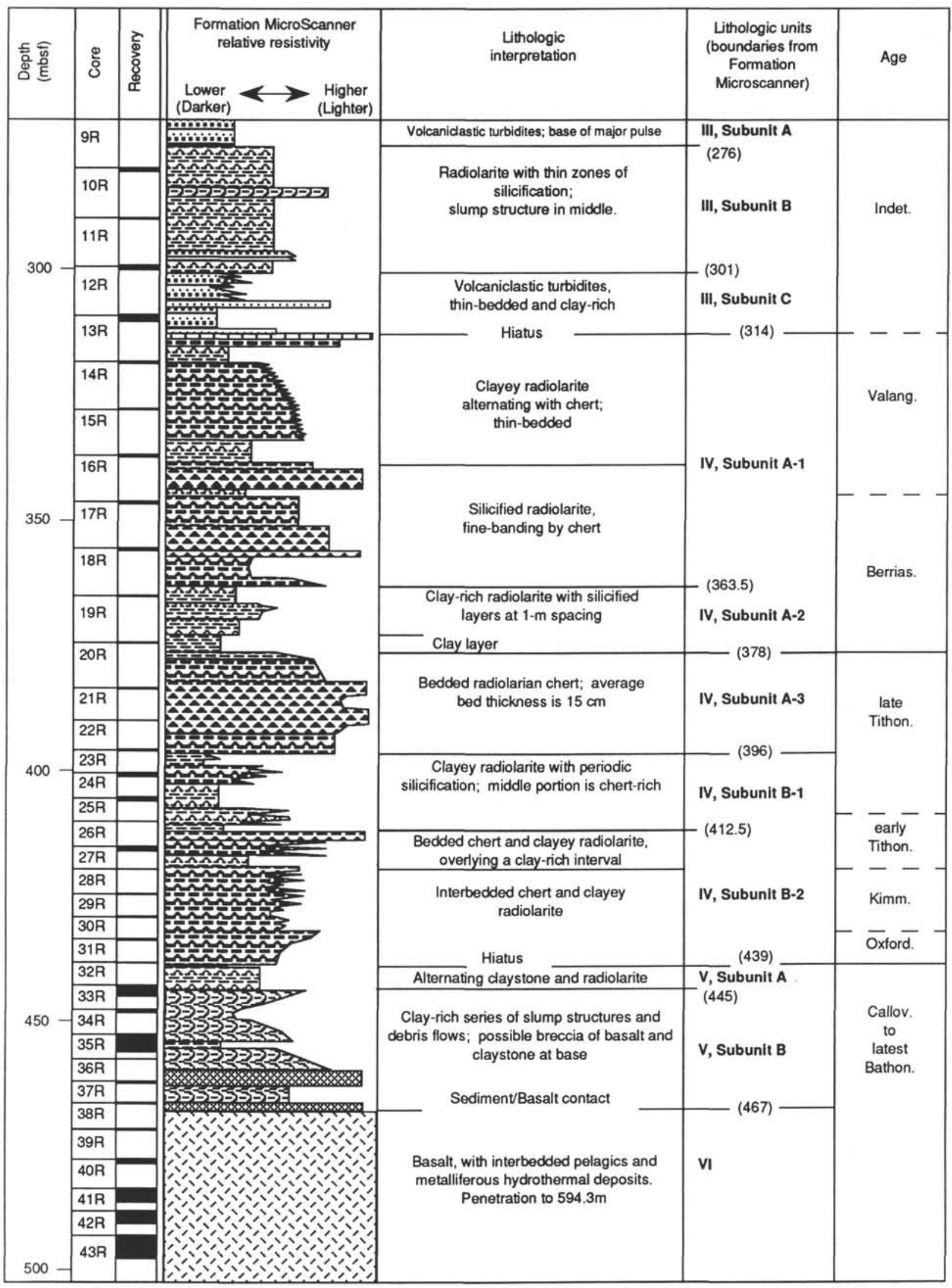

Figure 2. Jurassic and Lower Cretaceous stratigraphy. FMS interpretations of lithology and sedimentary structures, and of nature and depth of facies contacts, are supplemented by the limited shipboard recovery (shown at left). Lithologic units and biostratigraphic ages are according to the Site 801 shipboard stratigraphy (Shipboard Scientific Party, 1990). Identification and boundaries of lithologic subunits and depth of major hiatuses are according to the FMS logging depths in Hole 801B. 


\section{LEGEND}

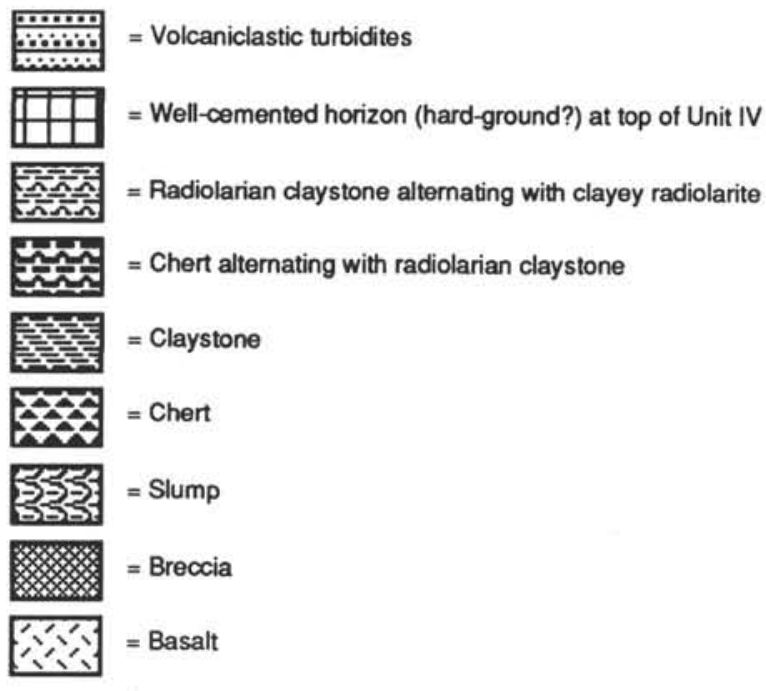

Figure 2 (continued).

\section{Core $129-801 B-35 R(452.3-456.9 \mathrm{mbs} f)$}

Claystone and Clayey Radiolarite with Variable Thicknesses of Radiolarian Sands; Pieces Display Shallow to Steep Apparent Dips

454.4-456.0 mbsf: Very low-resistivity zone containing mottling at the $20-\mathrm{cm}$ scale caused by slightly higher resistivity (Fig. 3). Coherent sedimentary bedding is absent. This lowest significant interval of low-resistivity material within lithologic Unit V is interpreted to be a clay-rich zone.

453.0-454.4 mbsf: Abundant mottling at the 50-cm scale caused by greater resistive material. No coherent bedding is observed. Mottles contain internal mottles or spots of higher resistivity.

450.2-453.0 mbsf: Zone of lower average resistivity than the underlying interval. The imagery is dominated by mottles of slightly higher resistivity, $1 \mathrm{~m}$ thick, with internal small-scale mottling and scattered high-resistivity spots or clasts (Fig. 3). Interval from 451.6 to 453.5 mbsf displays high-angle contacts between blocks (not bands) of higher and lower resistivity with dips of $50^{\circ}$ to $60^{\circ}$. These blocks of variable resistivity could be steep-dipping beds or large rotated clasts within a slump. This interpretation is supported by the presence of blocks of radiolarite dipping at high angles within a claystone within Core 129-801B-35R.

\section{Core 129-801B-34R (447.6-452.3 mbsf)}

\section{Alternations of Claystone and Radiolarite; Drilling Distorted Structures?}

446.0-450.2 mbsf: Low-resistivity zone with lowest relative resistivity values at 448.2-450.2 mbsf (Fig. 3) and a slight upward increase in general resistivity above 446 to $447 \mathrm{mbsf}$. Scattered rounded spots or "clasts" of high resistivity are 3 to $5 \mathrm{~cm}$ in diameter. No coherent bedding is present, and some steep-dipping (up to $60^{\circ}$ ) apparent contacts are noted. The "drilling distorted?" features noted in Core 129-801B-34R are irregular pieces of clayey radiolarite surrounded by claystone. However, the spotted character of the FMS images suggests that this interval has the same texture as the recovered core, and a clay-rich matrix encloses clasts of radiolarite. We interpret this feature to be a slump-distorted layer or a debris flow. There is an increase in radiolarian content above $447 \mathrm{mbsf}$.

\section{Core $129-801 B-33 R(442.8-447.6 \mathrm{mbsf})$}

Alternations of Radiolarite and Claystone with 5-cm Spacing; $27^{\circ}-$ $30^{\circ}$ Apparent Dips

444.8-446.0 mbsf: Higher resistivity than the underlying unit, but is still within a broad low-resistivity interval. Vague banding is observed on some traces, but no actual bedding can be identified. Some high-resistivity "clasts" are observed. Interval 444.8-445.3 mbsf may represent a transition of partially coherent banding below the overlying lithologic Subunit VA.

444.8 mbsf: Lowest level at which distinct sedimentary banding is observed.

General interpretation: The interval from 444.8 to $466.1 \mathrm{mbsf}$ consists of a series of slump deposits or debris flows which have distorted the original sedimentary bedding and created a chaotic mixture of clay-rich (lower resistivity) and clay-poor mottles containing fragmented pieces of more cemented radiolarite (Fig. 3). This interpretation is based upon the absence of coherent banding, the irregular and steeply dipping contacts between blocks having contrasting relative resistivities, and the presence of "clasts" or mottles of higher resistivity material scattered within a less resistive matrix. Based upon the sediments recovered from this interval, the facies consists of disrupted beds of radiolarite within a clay-rich matrix.

The top of this slump-dominated interval is tentatively correlated with the upward change from blocks within a clay-rich matrix to well-banded radiolarite/claystone occurring at the $95-\mathrm{cm}$ level of the recovery in Core 129-801B-33R. A downward increase from 456 to 466 mbsf in the average degree of silicification may represent diagenetic features associated with silica-rich hydrothermal influence from underlying basalts and/or a downward increase in radiolarian content.

\section{Upper Portion of Lithologic Unit V (Callovian): Subunit VA}

442.5-444.8 mbsf: Close-spaced banding is caused by low-contrast resistivity differences. Bands, 1 to $2 \mathrm{~cm}$ thick, of slightly higher resistivity are semi-evenly spaced at 3 - to $4-\mathrm{cm}$ intervals. Beds have apparent dips of $15^{\circ}$ to $20^{\circ}$. Recovery in Core 129-801B-33R indicates that this low-contrast banding is caused by interbedding of unsilicified granular layers composed of silt-sized radiolarians with claystones of similar porosity; therefore, both layers have similar resistivities.

\section{Core 129-801B-32R (438.2-442.8 mbsf)}

Inadequate Recovery; Probably Caving from Overlying Clayey Radiolarite

439.4-442.5 mbsf: This zone of generally low resistivity has close-spaced banding at 3- to 4 -cm scale (Fig. 4). Beds have about $20^{\circ}$ dip. Compared to the underlying unit, the banding has thicker beds with a greater resistivity contrast, otherwise it also represents well-defined alternations of clay and of radiolarite "silt" layers.

General interpretation: The interval from 439.4 to $444.8 \mathrm{mbsf}$ has close-spaced alternations of claystone and of unsilicified, granular radiolarian "siltstone" with similar resistivities (Fig. 4). There is a general upward increase in contrast between the bands of claystone and of radiolarite. Beds have dips of $20^{\circ}$. The lower portion of lithologic Unit V consists of a series of slumps and debris flows, and the interval of undisturbed Callovian strata comprises only this $5.4 \mathrm{~m}$ portion. 


\section{ORIENTATION NORTH}
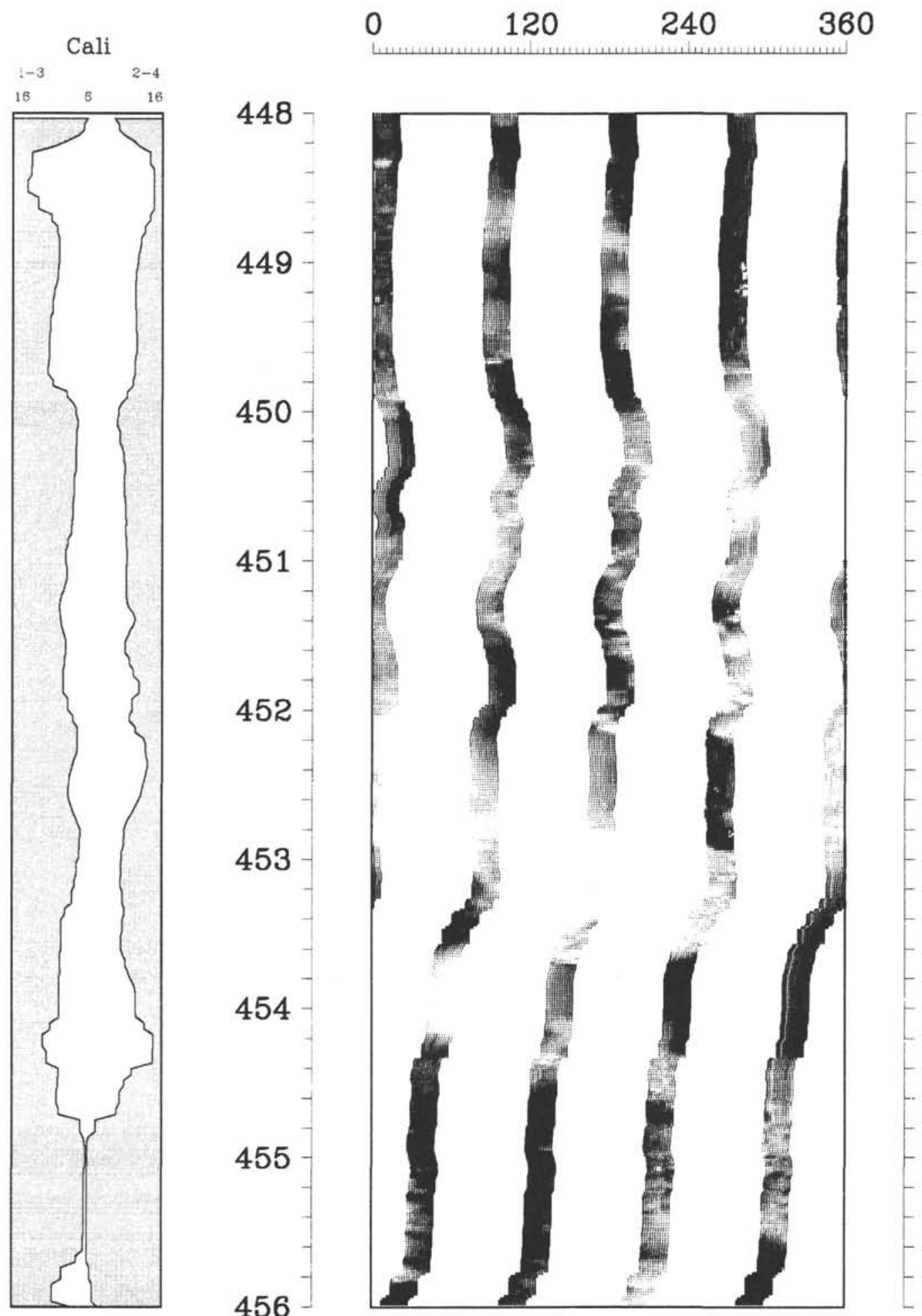

Figure 3. FMS static-processed image and caliber of borehole dimensions from the lower portion of lithologic Subunit VB of Callovian age (456.0 to 448.0 mbsf; corresponding to Cores 129-801B-35R and -34R). Gray scale for relative resistivity has been linearly adjusted over this 8 -m interval so that the highest resistivity beds are shown in white and the lowest is in black. Mottling by more resistive sediment, displayed in shades of lighter gray, dominates at the meter scale and has internal mottles or spots of greater resistivity. A small-scale mottling is also visible throughout the lower resistivity (darker) portions of this interval. No coherent sedimentary bedding is observed, although contacts between zones of contrasting resistivity display high-angle dips with variable orientations. Recovered core lithologies consist of red-colored claystone with pieces of more coherent clayey radiolarite having apparent dips ranging from $60^{\circ}$ to horizontal. This interval is interpreted to be a thick series of slumps which have distorted the original sedimentary bedding and created a chaotic mixture of clay-rich (lower resistivity) and clay-poor mottles containing fragmented pieces of more cemented radiolarite. The irregular borehole dimensions (radius ranges from $6 \mathrm{~cm}$ to $14 \mathrm{~cm}$ ) is probably due to differential washouts and low competency of these clay-rich sediments. 


\section{ORIENTATION NORTH}
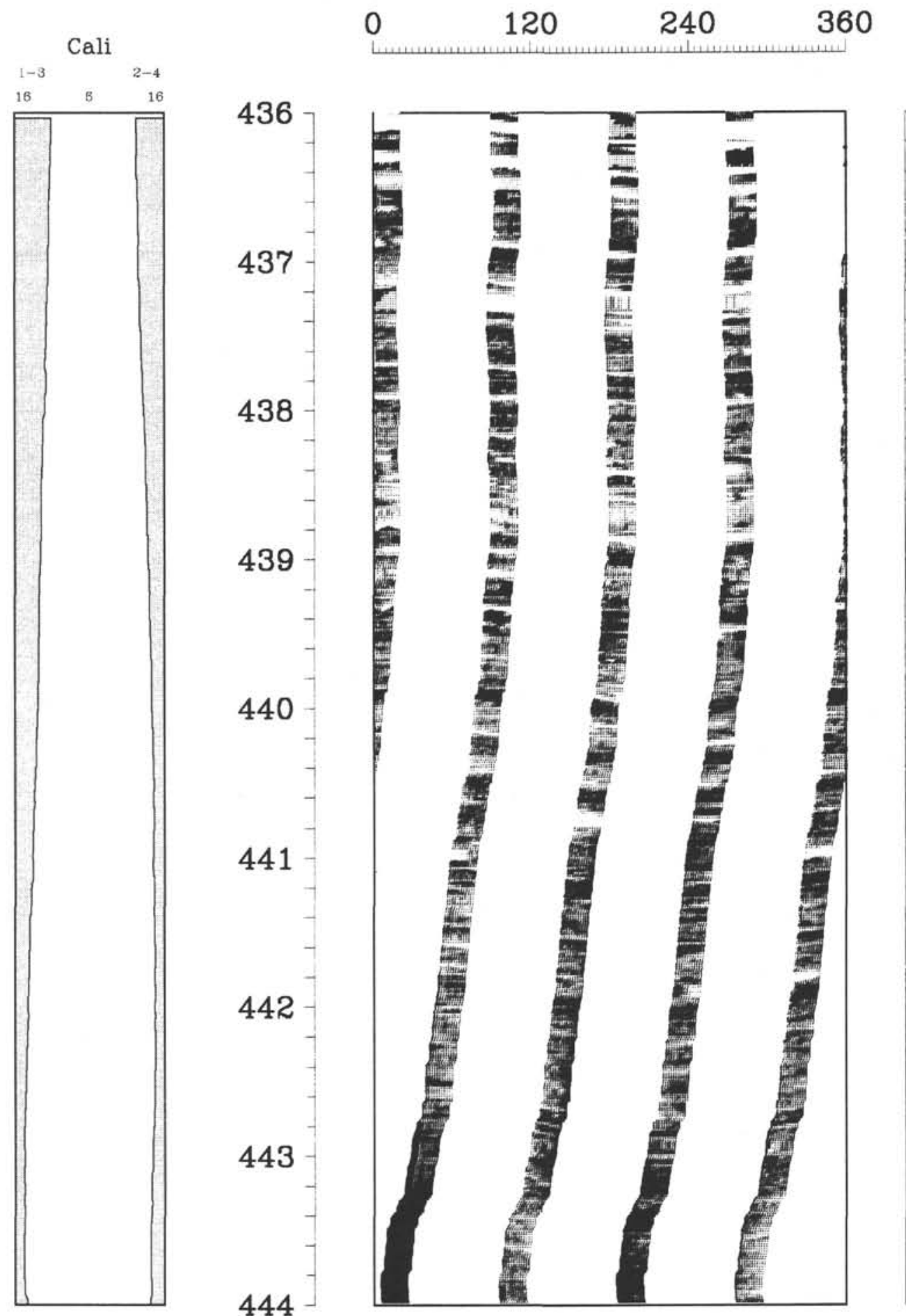

Figure 4. FMS static-processed image and caliber of borehole dimensions from the upper portion of lithologic Subunit VB of Callovian age and lower portion of lithologic Subunit IVB of Oxfordian-Kimmeridgian age (444.0 to $436.0 \mathrm{mbsf}$; corresponding to uppermost Core 129-801B-33R to lower Core 129-801B-31R). Gray scale for relative resistivity has been linearly adjusted over this 8 -m interval so that the highest resistivity beds are shown in white and the lowest is in black. Close-spaced alternations of relatively high-resistivity (light gray) and low-resistivity (dark gray) bands occur at 3- to 4-cm intervals within the Callovian strata (below $439 \mathrm{mbsf}$ ) and at $4-$ to $7-\mathrm{cm}$ intervals within the overlying Oxfordian. The Callovian banding displays less contrast in resistivity and has dips of approximately $20^{\circ}$ toward the northeast or southwest, but is not visually distinct at the 1:40 scale of this reproduction. The Oxfordian alternations are lenticular to banded, dip at approximately $14^{\circ}$ toward the southwest, and have an overall higher average resistivity than the Callovian beds. Core recovery indicates that the Callovian banding is caused by alternations of claystone and granular radiolarite, whereas the Oxfordian banding is due to clayey radiolarite with chertified bands and lenses. The contact between Callovian lithologic Unit V and Oxfordian lithologic Unit IV is within the zone between 439.0 and 439.4 mbsf. The downward widening in the smooth borehole diameter correlates with the downward increase in clay content, indicated by the general lesser resistivity values (darker gray). 


\section{Lower and Middle Portions of Lithologic Subunit IVB (Oxfordian-Kimmeridgian): Subunit IVB-2}

Core 129-801B-31R (433.6-438.2 mbsf)

Chert with Filled Fractures and Clayey Radiolarite

439.0-439.4 mbsf: An indistinct zone separates the underlying formation of $20^{\circ}$-dipping, close-spaced, low-contrast banding from the overlying formation of shallower dipping, wider-spaced, greatercontrast banding with overall higher resistivity (Fig. 4). The Callovian-Oxfordian hiatus, as deduced from biostratigraphy and the sharp change in facies (Shipboard Scientific Party, 1990; Ogg et al., this volume), is assigned as $439.4 \mathrm{mbsf}$, but could be as high as 439.1 mbsf. The unconformity interval lacks distinct sedimentary structures for about $1 \mathrm{~m}$ (439-440 mbsf). Geochemical logs indicate an upward decrease in silica content at 440 mbsf, consistent with the observed overall increase in relative resistivity.

436.1 $-439.0 \mathrm{mbsf}$ : High-resistivity bands and lenses, 4 to $7 \mathrm{~cm}$ thick, are irregularly spaced $(25$ to $40 \mathrm{~cm}$ ) within a zone having a lower average resistivity than either the underlying or overlying intervals (Fig. 4). Recovered sediments in Core 129-801B-31 indicate that this represents a clayey radiolarite containing scattered chert lenses and bands.

434.2-436.2 mbsf: This interval has slightly greater average resistivity than the underlying zone, but less than the overlying unit. Very thin bands of high resistivity, 1 to $4 \mathrm{~cm}$ thick, are spaced at $5-\mathrm{cm}$ intervals within less resistive sediment. Many of these high-resistivity layers display lateral pinch-outs and are probably beds and lenses of chert or porcellanite within a clay-rich radiolarite.

$432.0-434.2$ mbsf: Abundant thin high-resistivity (chert) beds, $5 \mathrm{~cm}$ thick, have a regular $15-\mathrm{cm}$ spacing. This is a relative thick zone characterized by greater average resistivity than the adjacent intervals and contains thicker clusters of high-resistivity beds than in the overlying unit.

\section{Cores 129-801B-28R through -30R (419.4-433.6 mbsf)}

Chert with Filled Fractures and Clayey Radiolarite; Poor Recovery

419.4 432.0 mbsf: Periodic clusters of high-resistivity bands (chert) are separated by intervals of low-resistivity (higher clay content) sediment having less-distinct banding. The high-resistivity clusters are about $50 \mathrm{~cm}$ wide, and consist of a central group of 1 to 3 major beds, $5-10 \mathrm{~cm}$ thick, bordered by thinner beds. The recovered core material indicate that these clusters of high-resistivity beds are packets of chert bands. Centers of these chert concentrations are at $419.7 \mathrm{mbsf}, 420.4$ (single bed), 421.0 , 422.1, 423.1 (less distinct), 424.2 (mainly a single 10-cm-thick bed), $425.1,426.6,427.6,429.8$, and 431.2 mbsf. The lowest three chert concentrations are more subdued in resistivity contrast and contain thinner individual chert beds than the higher clusters. A chert-rich cluster is lacking in the $428-429$ mbsf interval to fit this apparent cyclicity.

Low-resistivity (high clay) intervals between these chert concentrations are also about $50 \mathrm{~cm}$ wide and have a "speckled" resistivity pattern, suggesting irregular silicification. Core recovery indicates that these intervals correspond to clayey radiolarite with a "woody" texture caused by patchy distributions of clay-enrichment and silicification (Shipboard Scientific Party, 1990; Ogg et al., this volume). Siliceous bands (greater resistivity) within these clay-rich intervals are generally lenticular or irregular. HILITE-processed images over the 421-425 mbsf interval display an average spacing of $15 \mathrm{~cm}$ between individual beds or major lenses of high-resistivity silicification.

\section{Core 129-801B-27R (414.7-419.4 mbsf)}

\section{Clayey Radiolarite with Chert}

416.9-419.4 mbsf: This zone has lower average resistivity, but is spotted or mottled with patches of higher resistivity and contains some thin bands of higher resistivity. The general character is similar to the underlying 422.5-426.0 mbsf interval. Core recovery indicates that this interval includes clay-rich radiolarite with patches and thin beds of porcellanite and chert. The sharp lower boundary of this unit to the underlying banded-chert-rich interval may represent a minor discontinuity in sedimentation at 419.4 mbsf.

\section{Core $129-801 B-26 R(410.0-414.7 \mathrm{mbs})$}

\section{Pieces of Clayey Radiolarite and Chert; Insignificant Recovery}

414.0-416.9 mbsf: Three, 50-cm-thick clusters of high-resistivity (chert) beds are formed by groups of 10 - to $15-\mathrm{cm}$-scale bands and lenses. These clusters, interpreted as concentrations of chert beds, are separated by low-resistivity (clay-rich) intervals, $50 \mathrm{~cm}$ thick, containing discontinuous thin ( $5 \mathrm{~cm}$ thick) bands and small patches of partial silicification. Centers of the silicified clusters occur at 414.4, 415.7 , and $416.8 \mathrm{mbsf}$, indicating a $1.1-\mathrm{m}$ periodicity. This zone displays a much higher contrast in relative resistivity, hence of the degree of clay vs. chert enrichment, than the underlying zone.

412.3-414.0 mbsf: Zone of high average resistivity containing 11 distinct and continuous, $10-\mathrm{cm}$-scale, very high-resistivity beds. The middle $5 \mathrm{~cm}$ of each of these beds displays maximum resistivity. This zone is interpreted as a 1.7 -m interval of bedded chert. The thicknesses of the individual chert beds display a progressive upward decrease from $12 \mathrm{~cm}$ to $2 \mathrm{~cm}$ in width. This bedded chert zone and the underlying zone of periodic alternations of accentuated high/low silicification probably caused the poor recovery by Core 129-801B-26R.

General interpretation: Clusters of chert beds occur periodically within a banded clayey radiolarite. The poor core recovery is probably due to the $10-\mathrm{cm}$-scale alternations of hard and soft material and to the horizons of friable chert. There is an upward decrease in clay content in the lower $3 \mathrm{~m}$, followed by development of a general 1-m-scale periodicity of chertification. It appears that bands and lenses of silicification within the relatively clay-rich (less resistive) units are thinner and closer spaced than their character within silicarich (more resistive) units. This correlation between thicker silica-rich beds and increased silica content of the bulk sediment is also observed within the Lower Cretaceous radiolarite of lithologic Subunit IVA.

The spacing of silica-rich clusters is similar to the Milankovitch-eccentricity 100-k.y. cycles of overlying lithologic Subunit IVA (Molinie and Ogg, this volume). If the periodic silicification corresponds to these eccentricity cycles, the spacing would imply a $10-\mathrm{m} / \mathrm{m}$.y. sedimentation rate and a total time span for this $27-\mathrm{m}$ interval of approximately $3 \mathrm{~m}$.y. Spectral analysis of the window containing this interval (Molinie and Ogg, this volume) yields a sedimentation rate of $14.5 \mathrm{~m} / \mathrm{m}$.y.; however, this calculation is not reliable because the window width exceeds the thickness of this unit. A $10 \mathrm{~m} / \mathrm{m}$.y. rate implies that the $15-\mathrm{cm}$ spacing of chert bands/lenses has a cyclicity approximating the 20-k.y. Milankovitch periodicity for precession. One possibility is that the precession-modulated flux of radiolarians is superimposed on the eccentricity-modulated flux. However, an alternative possibility is that the $15-\mathrm{cm}$ spacing of beds and clusters is an artifact of periodic diagenetic segregation. This diagenetic alternative is supported by the observed increase in chert-bed thickness and spacing within more silica-rich zone, which could be partially due to the influence of clay content on compaction and on silica migration distances during diagenesis. These topics of periodicity and diagenesis are discussed in detail in Molinie and Ogg (this volume) and Ogg et al. (this volume).

\section{Upper Portion of Lithologic Subunit IVB (Lower Tithonian): Subunit IVB-1}

\section{Core 129-801B-25R (405.2-410.0 mbsf)}

\section{Clayey Radiolarite with Chert}

$407.5-412.5$ mbsf: This 5-m-thick zone of predominantly low resistivity has speckling and thin stringers of high-resistivity material. 
Based upon the core recovery, this zone is interpreted as clay-rich radiolarite with irregular patches and thin stringers of silicification. This relatively clay-rich interval begins at 412.5 mbsf and lacks significant chert beds or high contrast clustering of silicification. Geochemical logs also indicate a sharp upward decrease in silica content occurring at 413 mbsf. However, a few continuous high-resistivity (chert) bands, 5 to $10 \mathrm{~cm}$ thick, are present, especially at $408.3,409.0-409.7$, and $410.6 \mathrm{mbsf}$, and represent a low-contrast continuation of the underlying $1.1-\mathrm{m}$ periodicity in silica content. Average resistivity is gradually increasing toward the top of this interval; this trend is interpreted as an upward increase in the average degree of silicification.

According to spectral analysis of the clustering of silicification (Molinie and Ogg, this volume), the basal contact of this low-resistivity zone at 412.5 mbsf corresponds to a sharp decrease in sedimentation rates.

\section{Core 129-801B-24R (400.6-405.2 mbsf)}

\section{Clayey Radiolarite with Chert}

402.8-407.5 mbsf: This 5-m-thick zone of very low resistivity contains only two concentrations, $25 \mathrm{~cm}$ thick, of high-resistivity bands and elongate lenses, centered at 404.7 and 405.8 mbsf. There are also minor concentrations of more resistive beds at 403.5 and 407.5 mbsf. Core recovery supports the interpretation of a clayey radiolarite interval containing scattered chert beds. HILITE-processed imagery reveals relatively more resistive (more silicified) bands or elongate lenses occur at about $15-\mathrm{cm}$ spacing.

\section{Core 129-801B-23R (395.9-400.6 mbsf)}

\section{Pieces of Clayey Radiolarite with Chert; Insignificant Recovery}

399.2-402.8 mbsf: This interval is characterized by high-contrast banding by about 26 bands or elongate lenses of high-resistivity (silicified) material which peak both in thickness and in closeness of spacing at $400.4 \mathrm{mbsf}$. Downward from this peak, the high resistivity (chert) beds become progressively thinner as interbeds becoming wider and less resistive. There is also an upward trend of gradual thinning of these silica beds, with a sharp cut-off at $399.2 \mathrm{mbsf}$ to the overlying clay-rich zone. Many of these siliceous bands are of intermediate resistivity and may be porcellanite.

396.4-399.2 mbsf: This zone of very low-resistivity (clay-rich) contains a 1-m-thick interval (397.2-398.2 mbsf) of anastomosing (splitting and re-merging) bands of high resistivity (chert) (Fig. 5).

General interpretation: These $16 \mathrm{~m}$ of relatively low resistivity sediment represent a clay-rich interval. The lower portion displays an $1-\mathrm{m}$ periodicity in silicification ( 7 levels in $7 \mathrm{~m}$ ), the middle portion has numerous bands of chert, and the upper portion has two, $80-\mathrm{cm}$ thick, very clay-rich intervals adjacent to a 1-m-thick interval of partial silicification.

Level 396.4 mbsf, the top of the uppermost clay-rich interval, is chosen as the contact of lithologic Subunit IVB-1 (clayey radiolarite) to overlying Subunit IVA-3 (radiolarite). This level is $5 \mathrm{~m}$ higher than the reduction in clay content as indicated on the gamma-ray log (401 mbsf), but is at the same level as the upward increase in silica according to the silica-geochemical log (396 mbsf). According to spectral analysis of Milankovitch cycles from the gamma-ray log (Molinie and Ogg, this volume) this change in average silica content also corresponds to an upward increase in sedimentation rates at $398 \mathrm{mbsf}$.

\section{Lower Portion of Lithologic Subunit IVA (Upper Tithonian): Subunit IVA-3}

\section{Cores 129-801B-20R to -22R (374.5-395.9 mbsf)}

Chert with Filled Fractures; Insignificant Recovery

393.1-396.4 mbsf: Bands of very high resistivity are interbedded by layers of relatively low resistivity (Fig. 5). These alternations are interpreted as beds and elongate lenses of chert interbedded with clayey radiolarite. HILITE-processed imagery indicate that the major chert beds (up to $25 \mathrm{~cm}$ thick) display fracturing and irregular patterns of silicification.

382.5-393.1 mbsf: This zone of extremely high resistivity is interpreted as being almost entirely silicified (Fig. 5). The irregular bands of high resistivity (chert) display an anastomosing or braided appearance. HILITE-processed images suggest the presence of several vugs and fractures; these features were also observed in the cored sediment. There are bands of lesser degrees of silicification, but essentially no clay-rich bands. Maximum relative resistivity (greatest degree of chertification) occurs at 388.0-391.3 and 382.5-385.3 mbsf.

377.6-382.5 mbsf: Average resistivity is decreasing. Semi-uniform high-resistivity (chert) layers ( 5 to $25 \mathrm{~cm}$ thick, with main ones averaging about $15 \mathrm{~cm}$ thick) are separated by progressively less siliceous interbeds ( 5 to $30 \mathrm{~cm}$ thick, averaging $20 \mathrm{~cm}$ thick). At 378.1-376.8 mbsf, the sharp decrease in average resistivity is apparently a rapid transition from chert-dominant to clay-dominant facies. Within this transition, interbeds between high resistivity (silicified) layers become progressively less resistive (more clay-rich), and the silicified layers change from banded to nodular in geometry.

General interpretation: A banded-chert facies extends $19 \mathrm{~m}$. This chert interval has bands which pinch, merge and braid, but does not display "ribbon-bedding." Numerous fractures and vugs are present, especially within the thicker beds. Similar sedimentary features are also common in Tethyan bedded-chert formations.

The upper contact to clay-rich sediment ( $377.6 \mathrm{mbsf}$ ) is approximately at the Jurassic/Cretaceous boundary and possibly indicates a hiatus between the Tithonian and the Berriasian-Valanginian strata. This top of the bedded chert is $7 \mathrm{~m}$ higher than the sedimentation-rate discontinuity as identified by spectral analysis ( $385 \mathrm{mbsf}$ ), and $6 \mathrm{~m}$ higher than the top of the silica-rich zone according to the total gamma-ray log (386 mbsf); however, it agrees with the silica-geochemical log (379 mbsf) and the lithologies recovered by coring. Nevertheless, the thicknesses for facies interval agree among the various logs, implying a downward displacement of $7 \mathrm{~m}$ for the gamma-ray log relative to the FMS and geochemical log runs within this high-silica zone. This mismatch of logging depths was observed for other features (A. Fisher, pers. comm.).

\section{Middle Portion of Lithologic Subunit IVA (Berriasian- Valanginian): Subunit IVA-2}

\section{Core 129-801B-19R (365.3-374.5 mbsf)}

\section{Pieces of Radiolarite and Chert; Insignificant Recovery}

373.2-377.6 mbsf: This zone of extremely low resistivity is interpreted to be a radiolarian claystone, in accord with its characteristics displayed on other logs (see below). Scattered nodules and lenses of slightly more resistive (partially silicified) material, 3 to $6 \mathrm{~cm}$ thick, comprise about $5 \%$ of the sediment, and are most abundant at $374.1 \mathrm{mbsf}$. Minimum relative resistivity, hence maximum clay content, is at 376.0-376.7 mbsf. Lesser concentrations of silicification are spaced about $1 \mathrm{~m}$ apart. HILITE-processed images of the claystone show a small-scale mottled appearance, but no banding.

370.1-373.2 mbsf: Zone of very low resistivity (clay-rich) containing some more resistive (siliceous) nodules up to $20 \mathrm{~cm}$ in diameter. An irregular band of relatively high resistivity (chert), 15 to $25 \mathrm{~cm}$ thick, is at $371.3 \mathrm{mbsf}$.

366.8-370.1 mbsf: This low-resistivity zone contains fine-banding and diffuse lenses by more resistive (partially silicified?) sediment. The greatest relative resistivity (peak of silicification) occurs at $367.6 \mathrm{mbsf}$.

$363.5-366.8$ mbsf: Zone of very low resistivity containing diffuse elongate lenses of slightly greater resistivity (partial silicification by porcellanite?). These lenses are about $5 \mathrm{~cm}$ thick and have about 15 - to 20 - $\mathrm{cm}$ spacing. 


\section{ORIENTATION NORTH}
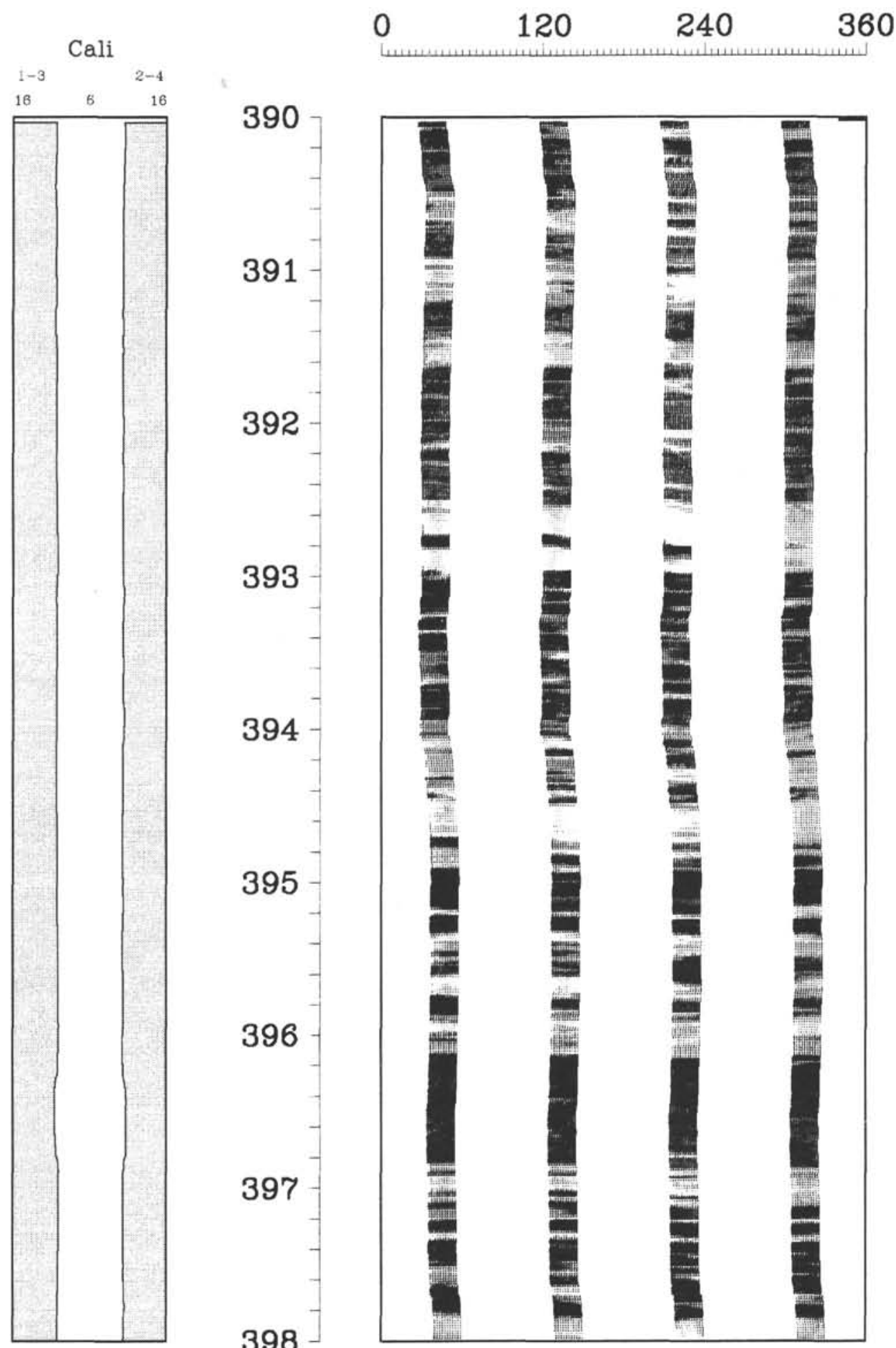

Figure 5. FMS static-processed image and caliber of borehole dimensions from the upper portion of lithologic Subunit IVB (lower Tithonian) and the lowermost portion of lithologic Subunit IVA (upper Tithonian) (398.0 to $390.0 \mathrm{mbsf}$; corresponding to Core 129-801B-24R and -23R). This zone has a relative high resistivity compared to the underlying Oxfordian-Kimmeridgian strata (Fig. 4) which, according to core recovery and geochemical logs, is caused by a greater abundance of chertification. Gray scale for relative resistivity has been linearly adjusted over this 8-m interval so that the highest resistivity beds are shown in white and the lowest is in black. The very low resistivity (clay-rich) zone at 397-396 mbsf marks the top of the clayey radiolarite facies of lithologic Subunit IVB. The overlying facies of high-resistivity (silicified) anastomosing bands represents the transition to a bedded chert. Another thin interval of anastomosing silicified bands occurs at the base of the image. The relatively smooth and narrow borehole (compare to Fig. 4) indicates a high degree of competency of this silica-rich interval. 
General interpretation: This facies is clay-rich compared to underlying and overlying lithologic units. Based upon the core recovery and relative resistivity, the lithology is interpreted to be dominated by clay-rich radiolarite. The basal $7.5 \mathrm{~m}$ is especially clay-rich and is defined on other geochemical logs, where it was interpreted as "an interval of radiolarite with volcanic clay" (Shipboard Scientific Party, 1990). Unfortunately, this clay-rich lithology was not recovered during coring. Zones of relatively higher silicification occur at approximately 1 -m spacing throughout this Subunit. The lowest occurrence of closespaced banding, which is the distinguishing characteristic of Subunit IVA-1, is at 370.1 mbsf.

\section{Upper Portion of Lithologic Subunit IVA (Berriasian- Valanginian): Subunit IVA-1}

\section{Core 129-801B-18R (355.8-365.3 mbsf)}

\section{Radiolarite and Radiolarian Chert}

361.7-363.5 mbsf: Zone of relatively high average resistivity. Bands of high resistivity, interpreted as chert beds, decrease upward in thickness from $30 \mathrm{~cm}$ to $5 \mathrm{~cm}$.

357.4-361.7 mbsf: Zone of relatively low average resistivity is finely banded by more resistive (siliceous) beds, 1 to $5 \mathrm{~cm}$ thick, at $5-\mathrm{cm}$ spacing. Alternating thin beds of radiolarite and of chert also comprise the recovered sediment.

356.5-357.4 mbsf: This basal meter of a relatively high resistivity (siliceous) zone is composed of beds of very high resistivity (chert).

\section{Core 129-801B-17R (346.6-355.8 mbsf)}

\section{Pieces of Radiolarite and Radiolarian Chert}

351.5-356.5 mbsf: Zone of high average resistivity. Anastomosing thin bands of higher resistivity (chert) are interbedded at $5-\mathrm{cm}$ spacing with less resistive (partially silicified) sediment (Fig. 6).

345.4-351.5 mbsf: This zone is intermediate in resistivity relative to underlying chert-rich and overlying clay-rich intervals. Thin banding at $5-\mathrm{cm}$ spacing is produced by continuous bands or elongate lenses, 2 to $4 \mathrm{~cm}$ thick, of high resistivity sediment (chert) (Fig. 6).

\section{Core 129-801B-16R (337.2-346.6 mbsf $)$}

\section{Radiolarian Chert and Radiolarite}

343.9-345.4 mbsf: Zone of lower resistivity relative to the underlying $12 \mathrm{~m}$. Discontinuous bands of higher resistivity occur at approximately $10-$ to $15-\mathrm{cm}$ spacing. Core recovery and geochemical logs suggest that this interval is predominantly composed of clayey radiolarite with diffuse stringers or bands of partial silicification (porcellanite?).

340.6-343.9 mbsf: Zone of high average resistivity. More resistive (chert) bands, 5 to $10 \mathrm{~cm}$ thick, occur with $15-$ to $20-\mathrm{cm}$ spacing interbedded with less resistive (partially silicified?) sediment.

339.0-340.6 mbsf: This zone is intermediate in resistivity relative to underlying more resistive (chert-rich) and overlying less resistive (clay-rich) intervals, and contains diffuse lenses of slightly higher resistivity (silification horizons).

334.9-339.0 mbsf: Low-resistivity zone containing distinct and continuous bands of very high-resistivity (cherts), 2 to $4 \mathrm{~cm}$ thick, spaced at 8- to $15-\mathrm{cm}$ intervals.

Cores 129-801B-15R, -14R, and Lower (Unrecovered?) Portion of $-13 R(313.0-337.2 \mathrm{mbsf})$

\section{Clayey Radiolarite with Chert}

318.7-334.9 mbsf: This zone, $16 \mathrm{~m}$ thick, is characterized by resistivity that is intermediate relative to the rest of Subunit IVA, and by thin continuous beds, 1 to $3 \mathrm{~cm}$ thick, of higher resistivity (chert and/or porcellanite) spaced at 4- to 6-cm intervals. A general upward decrease in average resistivity probably corresponds to an upward decrease in average silicification. Slight fluctuations in relative resistivity (degree of silicification) occur with about 1-m spacing.

315.7-318.7 mbsf: Zone of lower relative resistivity with a rapid transition from the underlying interval of decreasing resistivity (Fig. 7). Thin stringers of higher resistivity (partial silicification) occur at about $15-\mathrm{cm}$ spacing.

314.0-315.7 mbsf: Zone of unusually high resistivity, which we interpret as indicating a well-cemented or silicified sediment (Fig. 7). HILITE-processed images display thin irregular banding with $5-\mathrm{cm}$ spacing. No sediment was recovered from this interval. The top of lithologic Unit IV on the FMS traces is set at $314 \mathrm{mbsf}$; this is close to the sharp spikes seen in other logs (315 mbsf).

313.0-314.0 mbsf: This ultra-high-resistivity (?) zone is distorted on all traces (Fig. 7). HILITE-processed imagery suggests vague banding, but this is uncertain.

General interpretation: The upper $50 \mathrm{~m}$ of lithologic Subunit IVA consist of partially silicified radiolarite which is finely banded by chert (Fig. 6). The fine banding, generally at 5-cm spacing, may either be a diagenetic enhancement of primary periodic variations in radiolarian content (Ogg et al., this volume). From 357 to $316 \mathrm{mbsf}$, there is a general upward decrease in the average degree of silicification, and this trend is supported by the character of the limited core recovery. Silicification reaches a minimum just below a well-cemented zone at 314 mbsf (Fig. 7). The well-cemented zone at the top of lithologic Unit IV corresponds to a peak in $\mathrm{Si} / \mathrm{Al}$ on geochemical logs (Shipboard Scientific Party, 1990) and has the greatest relative resistivity observed within lithologic Unit IV. This high-resistivity horizon probably represents either a submarine exposure surface prior to the arrival of the overlying volcaniclastic turbidites and/or a lithification horizon enhanced by diffusion of silica downward from these overlying turbidites.

\section{Basal Portion of Lithologic Unit III (First Pulse of Volcaniclastic Turbidites; Post-Valanginian): Subunit IIIC}

\section{Upper Portion of Core 129-801B-13R (313.0-309.0 mbsf)}

Thin Clay-rich Turbidites Interbedded with Pelagic Radiolarian Claystone

312.1-313.0 mbsf: This zone of low to intermediate relative resistivity displays low-contrast thin-banding by parallel beds with about 4-cm average spacing (Fig. 7). Recovery in Core 129-801B$13 \mathrm{R}$ indicates that this facies consists of finely interbedded turbidite and pelagic radiolarite beds with variable silicification. The layers are too thin and fine-grained to resolve grading.

308.1-312.1 mbsf: Zone of very low resistivity. HILITE-processed images indicate parallel beds of variable thickness, averaging about 5 to $10 \mathrm{~cm}$ thick. These are probably clay-rich turbidites, but no unambiguous grading was observed in the imagery.

\section{Core 129-801B-12R (299.3-309.0 mbsf)}

\section{Volcaniclastic Turbidites; Sandstone to Claystone}

306.5-308.1 mbsf: Thicker (up to $40 \mathrm{~cm}$ ) beds of intermediate to high resistivity. The middle bed displays a sharp base of higher relative resistivity followed by an upward decrease in resistivity. Recovered turbidite beds indicate that this resistivity trend represents an upward grading from silt to clay-rich sediment. The other beds do not display sharp bases, but not unambiguous grading.

300.9-306.5 mbsf: Zone of low average relative resistivity with several slightly more resistive bands. This interval probably contains a series of turbidites of variable thickness. 


\section{ORIENTATION NORTH}
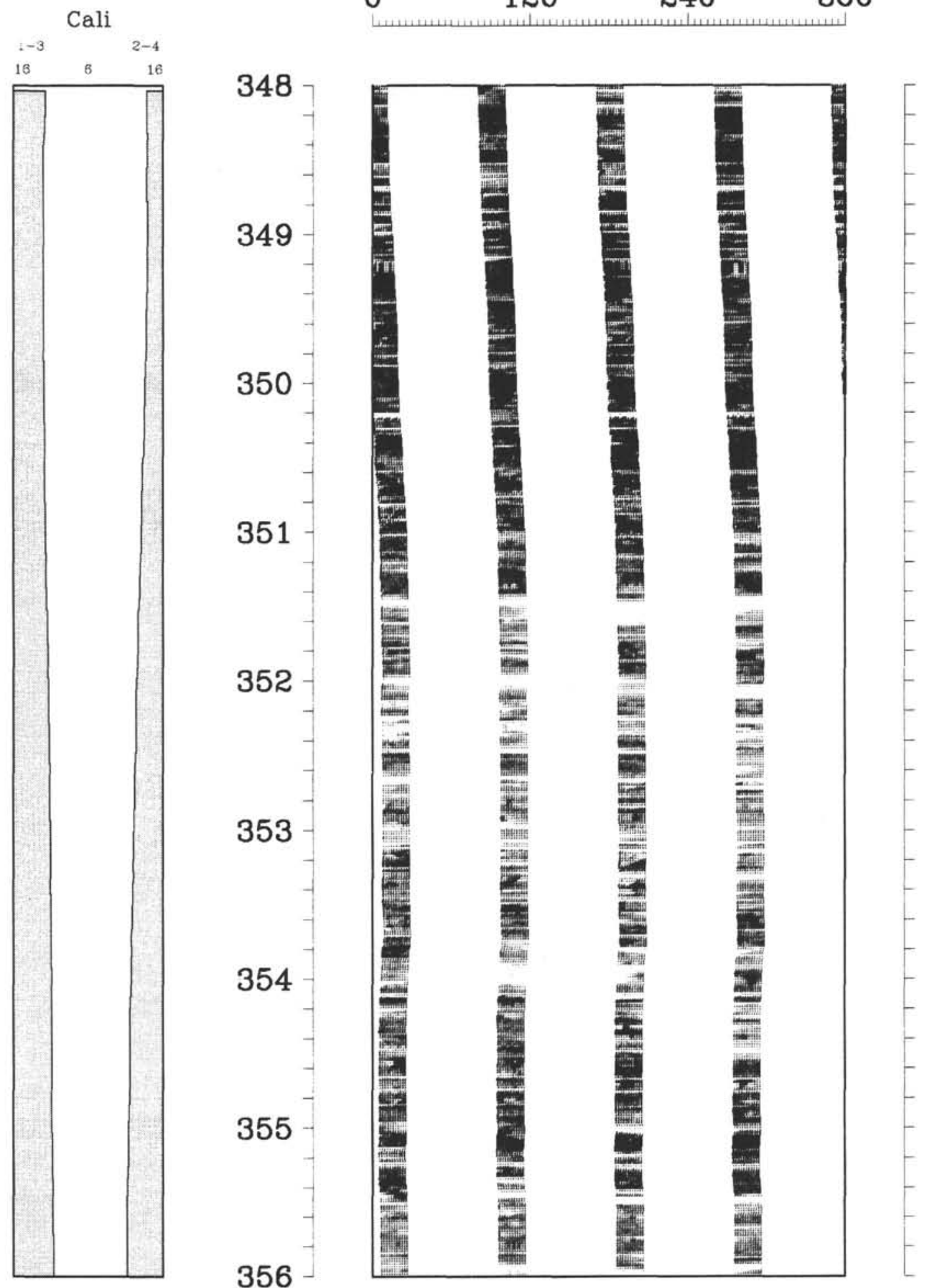

Figure 6. FMS static-processed image and caliber of borehole dimensions from the upper portion of lithologic Subunit IVA of Berriasian age (356.0 to 348.0 mbsf; corresponding to Core 129-801B-17R). Gray-scale for relative resistivity has been linearly adjusted over this 8-m interval so that the highest resistivity beds are shown in white and the lowest is in black. This sediment, typical of Subunit IVA, is characterized by thin alternations by high- and low-resistivity beds. Core recovery consists of brown-colored radiolarite, finely banded by radiolarian chert beds and lenses. The upward decrease in average resistivity and widening borehole diameter through this interval are interpreted to be caused by a gradual increase in clay content. 


\section{ORIENTATION NORTH}
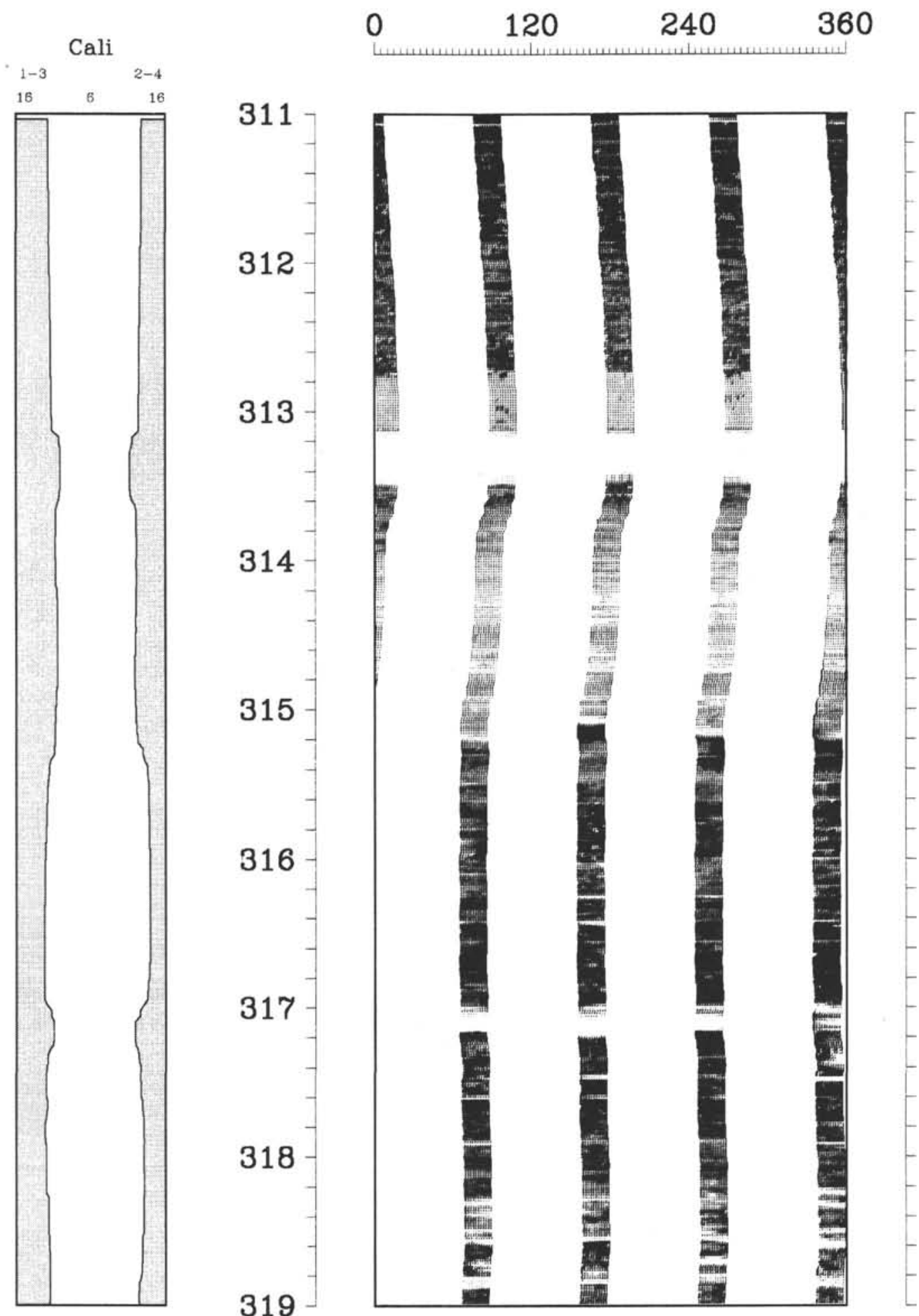

Figure 7. FMS static-processed image and caliber of borehole dimensions from uppermost lithologic Unit IV (Berriasian-Valanginian radiolarites) and the base of lithologic Unit III (pre-Aptian volcaniclastic turbidites) (319.0 to $311.0 \mathrm{mbsf}$; corresponding to Core 129-801B-13R). Gray scale for relative resistivity has been linearly adjusted over this 8 -m interval so that the highest resistivity beds are shown in white and the lowest is in black. The high-resistivity interval from 315 to $313 \mathrm{mbsf}$ corresponds to a peak of Si/Al geochemical log, indicating a silicified top of the radiolarite formation. This silification peak was not recovered during coring. Below this well-cemented horizon is low-resistivity sediment with more resistive layers spaced at 5-to 15 -cm intervals. Recovery of a similar facies in the underlying core indicates that this sediment is clayey radiolarite with stringers and bands of partial silicification. The uppermost interval of low resistivity appears to correspond to the series of thin clay-rich turbidites, 1 to $2 \mathrm{~cm}$ thick, recovered in Core 129-801B-13R. 
Lower Portion of Lithologic Unit III (Radiolarite; PostValanginian): Subunit IIIB

\section{Cores 129-801B-11R to -9R (270.3-299.3 mbsf), Respectively}

Pieces of Radiolarite and Porcellanite; Calcareous Claystone and Radiolarite; and Piece of Volcaniclastic Siltstone as Insignificant Recovery

285.2-300.9 mbsf: This zone has an intermediate-level average resistivity and displays banding of more and less resistive beds with approximately 3- to 7-cm spacing (Fig. 8). At 296.5-298.3 mbsf are two thick (up to $1 \mathrm{~m}$ ) moderate-resistive beds which do not display any internal structure other than a vague vertical change in average resistivity. These two thick beds are interpreted as turbidites. Other than these two beds, the FMS images of this $15-\mathrm{m}$ interval resembles the appearance of "typical" thin-bedded radiolarite of lithologic Subunit IVA-1; therefore, the facies is also interpreted as a radiolarite with thin parallel zones of silicification. The pelagic-dominated recovery of Core 129-801B-10R and $-11 \mathrm{R}$ support this interpretation.

283.9-285.2 mbsf: In contrast to adjacent intervals, these high-resistivity beds display high-angle $\left(60^{\circ}\right)$ irregular dips to the south (Fig. $8)$. This appears to be a slump structure.

281.5-283.9 mbsf: This zone of moderate average resistivity has very thin banding at about $4-\mathrm{cm}$ spacing (Fig. 8). The interpretation of a partially silicified radiolarite is supported by the core recovery.

\section{Middle Portion of Lithologic Unit III (Second and Major Pulse of Volcaniclastic Turbidites; Post-Valanginian): Subunit IIIA}

277.3-281.5 mbsf: Thick homogeneous beds of very low resistivity are interbedded by intervals of thin-banded high-resistivity facies. Internal structure of the thick, low-resistivity beds appears to consist of vague resistivity differences in a chaotic pattern. These homogeneous beds are probably the initiation of the major pulse of clay-rich volcaniclastic turbidites and are interbedded with partially silicified radiolarite.

263.1-277.3 mbsf: This zone predominantly consists of thick, homogeneous, low-resistivity beds, which are interpreted to be volcaniclastic turbidites. An interval of thin-bedded, intermediate resistivity sediment that dominates $265.4-277.3 \mathrm{mbsf}$ is possibly radiolarite, but no core recovery was obtained.

General interpretation: There is a minor episode of fine-grained volcaniclastic input from 300.9 to $313 \mathrm{mbsf}$ with only a few thicker beds. The next $20 \mathrm{~m}$ (281.5-300.9 mbsf) appear to be predominantly comprised of radiolarite with fine-banding of silicification. FMS images of this radiolarite facies are very similar to those of the underlying Lower Cretaceous lithologic Unit IV. A slump interval, $1.5 \mathrm{~m}$ thick, disrupts this radiolarite deposition (Fig. 8), but no significant turbidites were observed within this 20 -m interval.

The base of the second turbidite pulse is assigned to $281.5 \mathrm{mbsf}$, which supports the shipboard estimate of $280 \mathrm{mbsf}$ for the base of the major volcaniclastic Unit III. The characteristics of the FMS images of these redeposited beds are described in more detail by Salim (this volume).

\section{SILICIFICATION AND BEDDING CHARACTERISTICS OF LITHOLOGIC SUBUNIT IVA (LOWER CRETACEOUS)}

\section{Histograms of Formation MicroScanner Resistivity}

The detailed centimeter-by-centimeter resistivity logs from the FMS can be subjected to various statistical analysis techniques including spectral analysis of cyclicity and histograms of bed thickness or resistivity. As explained previously, the resistivity value is a good indicator of the degree of silicification of the radiolarites in Hole 801B. Clay-rich intervals have very low-resistivity values, unsilicified clayey radiolarite has intermediate values, porcellanite has a high value, and chert will have the highest resistivity. A histogram of the resistivity values from a given interval will reveal the average degree of silicification and the contrast between clay-rich and silicified layers.

We plotted histograms of relative FMS resistivities for a set of four 9-m sections from the Lower Cretaceous (Fig. 9 through 12). This set represents subdivisions of a single 36 -m contrast-adjusted interval; therefore, comparisons can be made among the set of relative resistivity. Three peaks of relative resistivity occur in most histograms: two intermediateresistivity "porcellanite" peaks on a general broad "siliceous claystone" mound, and a distinct, very high-resistivity chert peak.

The presence of two separate "porcellanite" peaks may represent the contrast between partial silicification of clayey radiolarite as a continuous band, and as a thin stringer or discontinuous nodular bed, which would display an average resistivity between porcellanite and the host unsilicified sediment on the FMS imagery bands.

The chert peak represents the mineralogical and density change between porcellanite and chert. Probably the resistivity values between porcellanite and chert are caused by the resolution averaging by the FMS sensors and signal processing (which has a continuous resistivity adjustment, as explained previously).

The relative breadth and amplitude of the broad "siliceous-claystone" mound within each 9-m interval is a rough indication of the average radiolarian/clay ratio and degree of porcellanite formation. The height of the porcellanite peaks above this broad mound is a partial reflection of the segregation of porcellanite beds.

In addition to the resistivity histograms, the distribution of thicknesses for the relative high-resistivity beds within each 9-m interval were determined (Fig. 13).

The degree and thickness of silicification according to histograms of relative resistivity were compared to the previous FMS lithology interpretations and to recovered sediments for each 9-m interval:

\section{Uppermost Lithologic Subunit IVB-1 of Bedded Chert and Lower Subunit IVA-3 of Clay-rich Radiolarite: 382.6-373.4 mbsf}

FMS lithology (Cores 129-801B-20R and -21R): Two facies are present. The lower chert-rich facies from 378 to $382 \mathrm{mbsf}$ is overlain by clay-rich from 373 to 378 mbsf. The chert-rich facies has beds averaging $15 \mathrm{~cm}$ thick.

Silicification histogram (Fig. 9): Dominated by a very high peak for chert. A distinct high-resistivity "porcellanite" peak is present, but is shifted toward higher values of resistivity, hence more siliceous, than in overlying sections; this silica-shift may be an indication of relatively less clay within the porcellanite. Other porcellanite peaks are absent. The "siliceous-claystone" mound is of relatively less importance than in the overlying sections, probably due to dominance by the silica peaks. However, the combination of a chert-rich lower zone and a clay-rich upper zone implies that the histogram is a mixture of two extreme facies.

Thickness of silicified beds (Fig. 13): Fairly even distribution between 2 and $15 \mathrm{~cm}$. A few beds up to $28 \mathrm{~cm}$ thick may be composed of adjacent chert bands.

\section{Lithologic Subunit IVA-2 of Clay-rich Radiolarite: 373.4-364.3 mbsf}

FMS lithology (Core 129-801B-19R): Clayey radiolarite. Upper portion has siliceous nodules, middle portion has 10 - to 15 - $\mathrm{cm}$ thick bands of chert, and lowermost meter contains large $20-\mathrm{cm}$ chert nodules. Chert-rich zones are spaced 1-m apart.

Silicification histogram (Fig. 10): Chert is of minor importance. The "low-resistivity porcellanite" peak is more important than the more silica-rich porcellanite peak. The "siliceous-claystone" mound peaks at the value of the low-resistivity porcellanite, suggesting that 


\section{ORIENTATION NORTH}
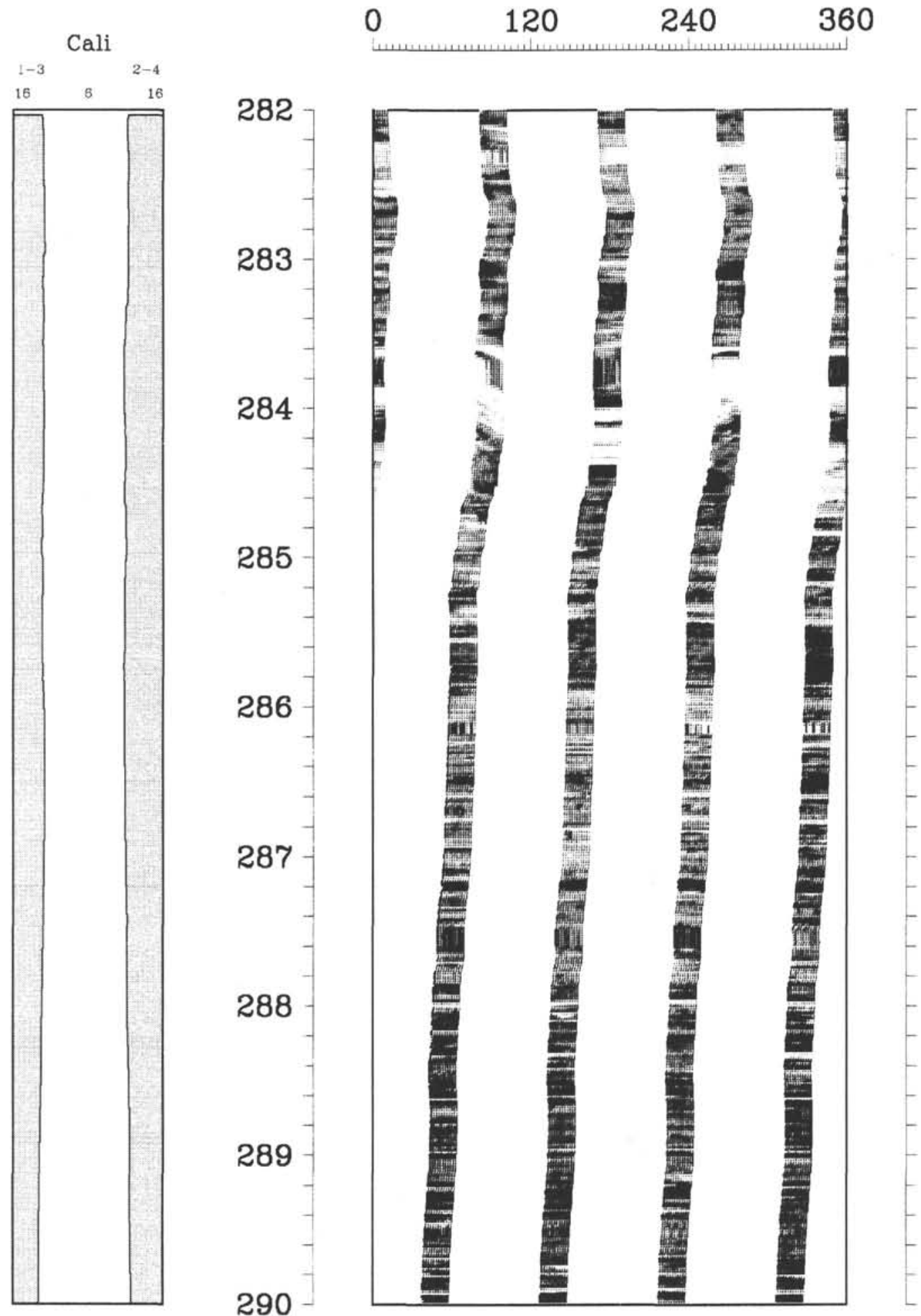

Figure 8. FMS static-processed image and caliber of borehole dimensions from lower lithologic Unit III (post-Valanginian radiolarites) (290.0 to 282.0 mbsf; corresponding to Core 129-801B-10R). Gray scale for relative resistivity has been linearly adjusted over this 8-m interval so that the highest resistivity beds are shown in white and the lowest is in black. The lower two-thirds of this image has banding by alternating more- and less-resistive beds with approximately 3 - to 7-cm spacing. This interval resembles the appearance of the thin-bedded radiolarite of lithologic Subunit IVA-1 (Fig. 6) and is interpreted to be a similar facies. Radiolarite with fine-banding of silicification recovered in Core 129-801B-10R supports this interpretation. At 283.5-285.0 mbsf are steeply dipping beds of relatively high resistivity, which appears to represent a slump-distorted interval within this succession. The overlying thin-bedded facies is probably a partially silicified radiolarite, similar to the underlying facies. 


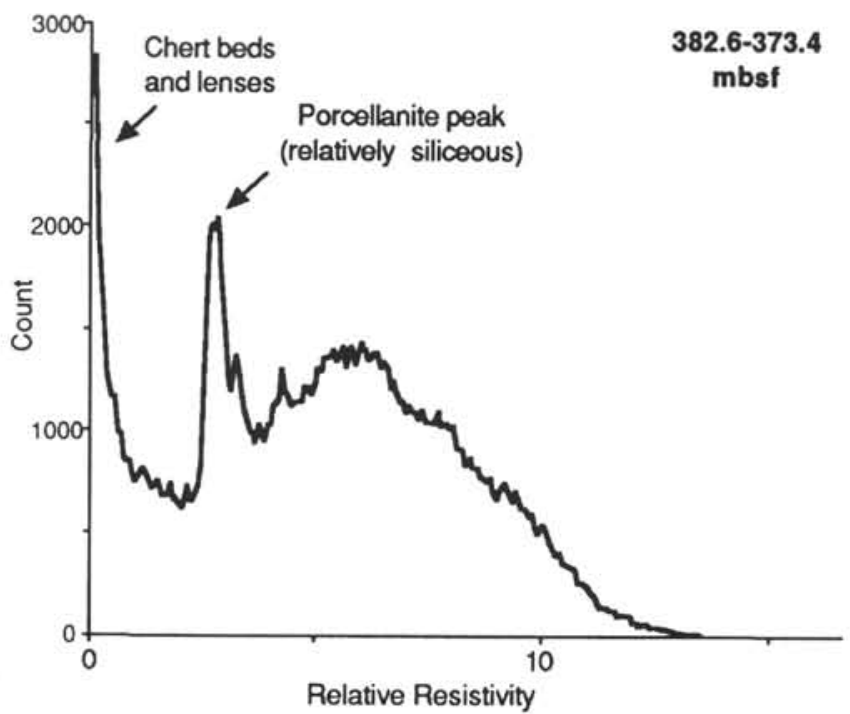

Figure 9. Relative abundances of silicification within $382.6-373.4 \mathrm{mbsf}$ (uppermost lithologic Subunit IVB-1 of upper Tithonian bedded chert and lower Subunit IVA-3 of Berriasian clay-rich radiolarite) from histogram of FMS resistivity measurements. Resistivity counts are scaled from low-resistivity "chert" at left to high-resistivity "clay" at right. A pronounced chert bed peak and a silica-rich porcellanite peak are distinct above the broad "silicifiedclaystone" mound.

there is not much resistivity contrast between the average sediment and the beds of porcellanite.

Thickness of silicified beds (Fig. 13): There are fewer silicified beds relative to the underlying and overlying sections. Thicknesses display a large degree of scatter, with beds thinner than $5 \mathrm{~cm}$ thick being most abundant. Beds thicker than $15 \mathrm{~cm}$ are rare.

\section{Lower Lithologic Subunit IVA-1 of Silicified Radiolarite: 364.3-355.1 mbsf}

FMS lithology (Core 129-801B-18R): Clayey radiolarite with some chert bands up to $20 \mathrm{~cm}$ thick.

Silicification histogram (Fig. 11): The chert peak is pronounced, and the high-resistivity porcellanite peak is more important than the low-resistivity less-siliceous one. The broad "siliceous-claystone" mound has a higher average resistivity than the underlying 9-m interval, suggesting an overall lower clay content.

Thickness of silicified beds (Fig. 13): Scattered distribution, but the majority of silicified beds are less than $5 \mathrm{~cm}$ thick. Some beds have thicknesses in the 20 - to 30 - $\mathrm{cm}$ range.

\section{Middle Portion of Lithologic Subunit IVA-1, Silicified Radiolarite: 355.1-346.0 mbsf}

FMS lithology (Core 129-801B-17R): Clayey radiolarite with minor porcellanite. Less siliceous than underlying core, with siliceous/clay-rich alternations at $5-\mathrm{cm}$ spacing.

Silicification histogram (Fig. 12): Virtual absence of chert. There are two sharp peaks for porcellanite, representing a contrast between more-siliceous and less-siliceous porcellanite compositions.

Thickness of silicified beds (Fig. 13): Thin-bedded, peaking at 2 -cm thicknesses. No significant beds exceed $5 \mathrm{~cm}$. This distribution of thicknesses agrees with the independent FMS observations and shipboard lithology.

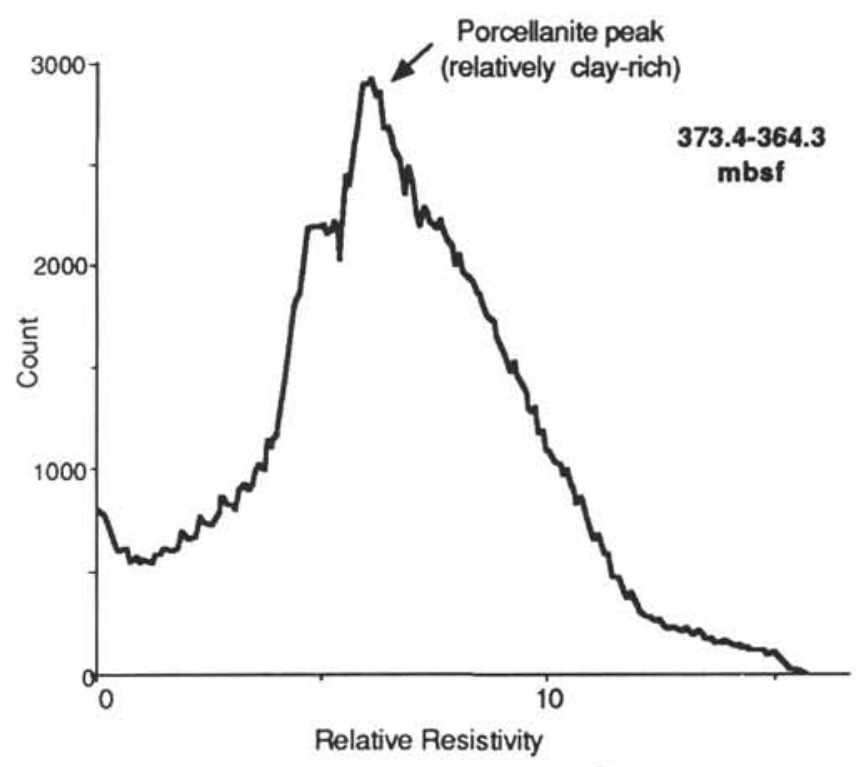

Figure 10. Relative abundances of silicification within $373.4-364.3 \mathrm{mbsf}$ (lithologic Subunit IVA-2 of Lower Cretaceous clay-rich radiolarite) from histogram of FMS resistivity measurements. Resistivity counts are scaled from low-resistivity "chert" at left to high-resistivity "clay" at right. Chert is rare, and facies is dominated by clayey porcellanite to "silicified claystone."

\section{CONCLUSIONS}

Pronounced chert peaks occur in the lowest unit (381.6-373.4 mbsf) and within 364.3-355.1 mbsf. This agrees with shipboard observations and FMS imagery interpretations.

The distinction between the porcellanite resistivity peaks, which are on the silica-rich side of a broad "siliceous-claystone" mound, and the chert resistivity peaks provides an important indicator of diagenetic segregation of clay-rich/silica-rich zones. In turn, these separation of peaks are an indicator of the original magnitude of variation in radiolarian/clay ratio. In intervals having important chert peaks, the porcellanite peaks are of lesser importance, and vice versa.

Intervals containing high abundances of chert also generally have thicker beds of silicification (Fig. 13). Where chert is absent (such as $355.1-346.0 \mathrm{mbsf}$ ), the silica-rich beds are very thin. This correlation of increasing thickness of silicified beds with an increase in average silica content of the sediment was also noted in the FMS interpretations. Growth of silica-rich beds may become slower as clay content increases. Where more clay is present (implying a lower abundance of siliceous radiolarians), the migration of silica and resulting nucleation of porcellanite-chert beds is inhibited. In addition, thicker silicified beds may result if the original sediment contained thicker zones having concentrations of radiolarians. High radiolarian contents provide an abundant silica supply and a lower porosity zone, enabling growth of thicker chert bands, spaced wider apart. This hypothesis requires verification through microfacies determination of the clay/radiolarian abundances in the recovered sediments and comparison to bedding character.

\section{CHERT-CLAY ESTIMATES FROM CALIBRATION OF DENSITY AND SONIC VELOCITY LOGS}

Core recovery of chert-rich and clay-rich intervals and logs of geochemical and physical properties support the interpretations of the FMS imagery that most of the Jurassic through Lower Cretaceous sediments in Hole 801B consist of variable amounts of clay enrich- 


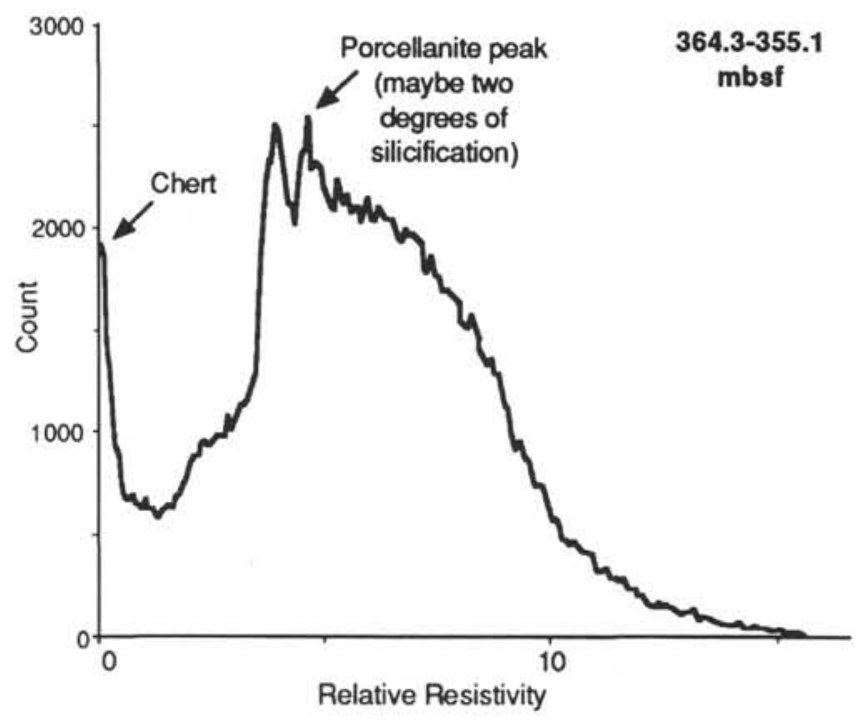

Figure 11. Relative abundances of silicification within 364.3-355.1 mbsf (lower lithologic Subunit IVA-1 of Lower Cretaceous silicified radiolarite) from histogram of FMS resistivity measurements. Resistivity counts are scaled from low-resistivity "chert" at left to high-resistivity "clay" at right. Facies is dominated by porcellanite and "siliceous claystone," with progressively lesser amounts of less-siliceous claystone. Chert beds and lenses are present.

ment and silicification. Density and sonic velocity values of characteristic chert and clay lithologies were obtained by shipboard physical property measurements (Shipboard Scientific Party, 1990). We used these values to calibrate the corresponding logs of density and sonic velocity within intervals known to be dominated by chert (lithologic Subunit IVA- 3 of bedded chert) and by clay (e.g., lithologic Subunit VB). These calibrated log responses were applied to the other intervals of Hole $801 \mathrm{~B}$ to yield a qualitative plot of relative abundances of chert and clay (Fig. 14).

The computational software employed for this application of calibrated logs is called Terralog (Terrasciences, Inc.) and was run on a Log Analyst System. The basic theory for the modeling of compositional components from logging data was developed by Savre (1963), and further improved by Burke et al. (1967) and by Dawnson-Grove and Palmer (1968). In this model, the log response for any zone is related to the sum of the proportions of the mineralogical/porosity components, each multiplied by the appropriate response coefficients of the different logging instruments. This procedure results in a series of simultaneous equations of the form:

$$
C_{1} V_{1}+C_{2} V_{2}+\ldots+C_{n} V_{n}=1
$$

where $n$ is the number of components, $C_{i}$ is the log response of the " $i$ 'th" component, and $V_{i}$ is the proportion of the " $i$ 'th" component.

In addition, the system is assumed to be composed only of these " $n$ " components; therefore, the proportions of the " $n$ " components will sum to 1, which gives us an additional equation to the set.

In our case, the Jurassic and Lower Cretaceous radiolarites were considered to be composed of variable proportions of two end-members of mineralogy and porosity: clay and chert. This dual-component assumption is based upon the observed shipboard recovery. The density and sonic velocity were measured on samples from this interval (see "Physical Properties" section in Shipboard Scientific Party, 1990). We used the following calibration values:

$\begin{array}{lc} & \text { Wet density }\left(\mathrm{g} / \mathrm{cm}^{3}\right) \\ \text { Clay } & 1.95 \\ \text { Chert } & 2.57\end{array}$

Sonic velocity $(\mathrm{km} / \mathrm{s})$

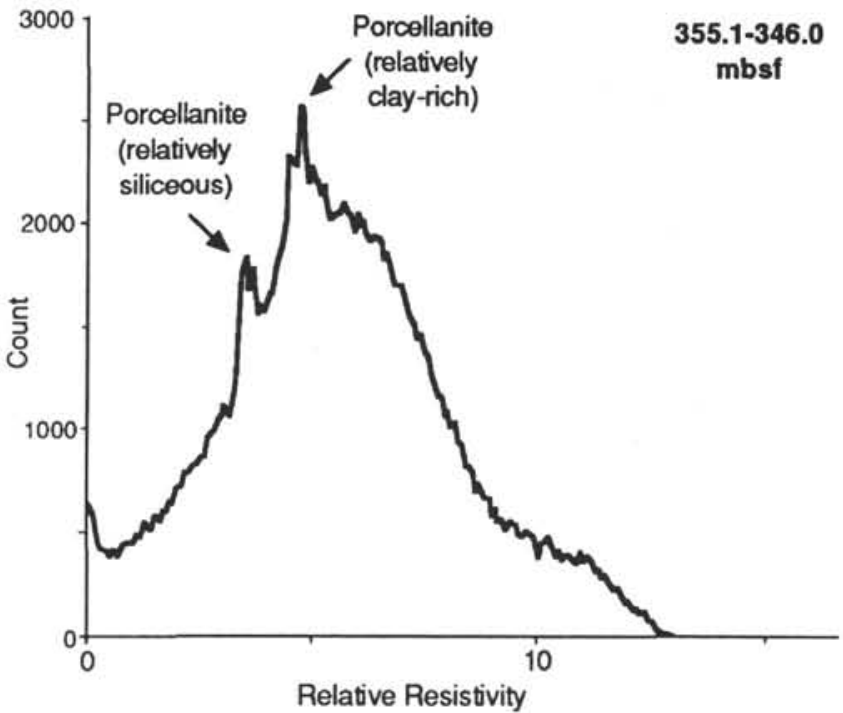

Figure 12. Relative abundances of silicification within $355.1-346.0 \mathrm{mbsf}$ (middle portion of lithologic Subunit IVA-1, Lower Cretaceous silicified radiolarite) from histogram of FMS resistivity measurements. Resistivity counts are scaled from low-resistivity "chert" at left to high-resistivity "clay" at right. The silicification of this interval is mainly between a porcellanite and a "siliceous claystone"; chert beds are rare.

We applied these calibrations to the density and sonic velocity logs using the Terralog software. The material balance provides a third equation; therefore, the software computed a least-squares approximation to the over-determined solution of these three equations with two unknowns. Density and sonic velocity logs record the average values over approximately a $30-\mathrm{cm}$ interval; therefore, we consider this clay/chert plot to represent the average degree of silicification of the sediment. There is an excellent consistency between this independent computation of degree of silicification and the interpretation of lithologies from the FMS imagery (Fig. 15), although this comparison is circular for the two intervals selected for the calibration points.

There is a general long-term trend of increasing silica content within the sediment from Callovian through upper Tithonian (Fig. 15). Chert content reaches a peak in the upper Tithonian bedded-chert formation of lithologic Subunit IVA-3. The overlying Berriasian-Valanginian is relatively clay-rich, with a brief pulse of silicification occurring at the base of lithologic Subunit IVA-1 or at about 355 mbsf.

Within these broad trends are several short-term, but high-amplitude, fluctuations. These short-term fluctuations in silica or clay content are also evident on the silica and gamma-ray intensity logs, but the chert/clay ratio method amplifies these features. For example, the hiatus at the Callovian/Oxfordian boundary (top of lithologic Unit V) is marked by a spike in silicification. Just before the onset of the upper Tithonian bedded chert is a clay-rich layer; another clay enrichment is above this bedded chert. At a finer scale, the peaks in silica or clay have been interpreted to be responses to Milankovitch cycles of eccentricity with 413-k.y. and 100-k.y. periodicity (Molinie and $\mathrm{Ogg}$, this volume). Within these cyclic variations, the recovered sediment and FMS imagery reveal even finer fluctuations in silicification down to $5 \mathrm{~cm}$ or less.

\section{DIPMETER MEASUREMENTS OF STRATA}

The FMS logging string includes a dipmeter (Schlumberger's Stratigraphic High-Resolution Dipmeter Tool). This tool records the resistivity curves from eight measuring electrodes, two on each of 

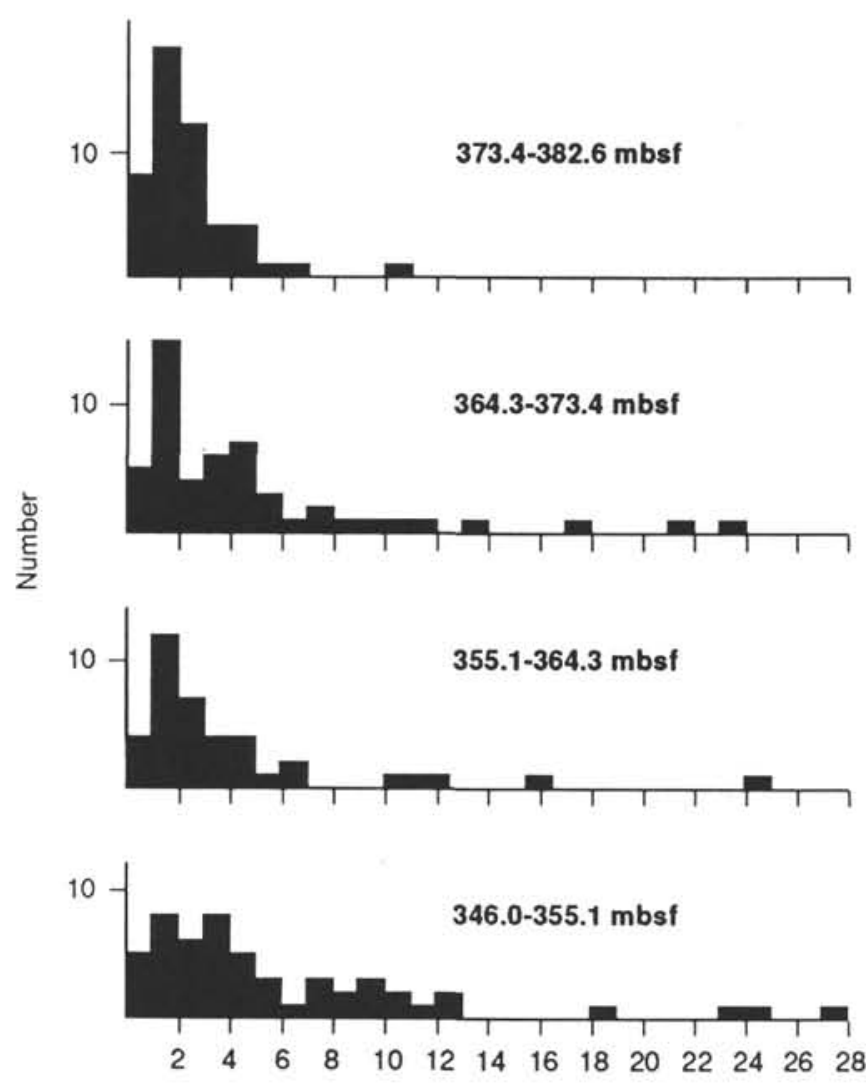

Thickness $(\mathrm{cm})$

Figure 13. Thickness of chert and porcellanite beds and lenses at different stratigraphic intervals within the upper Tithonian and Lower Cretaceous radiolarite. Silicified beds are identified as being intervals of high resistivity on the FMS logging traces. In general, silicified beds are thinner within the more clay-rich intervals. Upper Tithonian bedded chert (382.6-373.4 mbsf) displays the most abundant thicker beds, especially in the $8-$ to $15-\mathrm{cm}$ range. Porcellanite layers in Lower Cretaceous clayey radiolarite are typically less than $5 \mathrm{~cm}$ in thickness.

four pads mounted at $90^{\circ}$ angles. Resistivity events recorded on this array of pads are then correlated. The offset in vertical distance for events, combined with the simultaneous calibration of hole diameter, yields the mean square dip of the structure. A magnetometer on the tool enables determination of the direction of dip. The instrument and processing is described in more detail in Schlumberger $(1983,1986)$ and by Höcker et al. (1990). The resulting graph of dip and dip direction of structures compliments similar determinations made from the FMS images (Serra, 1989).

Lower and middle Callovian sediments of lithologic Subunit VB, which we have interpreted as slump deposits or debris flows, display "contacts" that randomly dip from $1^{\circ}$ to $75^{\circ}$, with no coherent directions. Upper Callovian strata between 448 and 439 mbsf also have scattered dips, but display an average trend of about $20^{\circ}$ dip toward the northeast or southwest (both orientations are recorded in equal amounts).

Oxfordian clayey radiolarite from 439 to approximately $427 \mathrm{mbsf}$ displays an average dip of $14^{\circ}$, which is consistently toward southwest. This dip is not well defined on the FMS images. The overlying Kimmeridgian through Tithonian strata from 427 to $378 \mathrm{mbsf}$ dip consistently at approximately $7^{\circ}$ toward southwest.

The lowest strata of Berriasian age, from 378 to about $363 \mathrm{mbsf}$ (lithologic Subunit IVA-2), display irregular shallow dips, perhaps caused by undulatory bedding of the silicified layers. The radiolarites of lithologic Subunit IVA-1 have a mean dip of $2^{\circ}$ to $4^{\circ}$ toward southwest to west, except for a short $10^{\circ}$ eastward-dipping unit at 328-322 mbsf. The first episode of distal volcaniclastic turbidites (lithologic Subunit IIIC) has a $1^{\circ}$ dip toward the south. The second volcaniclastic episode yielded apparent dips of $2^{\circ}$ to $10^{\circ}$ with random orientations, perhaps caused by cross bedding or undulatory basal scour by these beds.

In summary, most of the Upper Jurassic strata consistently dip toward the southwest at about $7^{\circ}$, whereas the underlying Callovian strata have steeper dips with variable orientations. Lower Cretaceous pelagic sediments dip at approximately $2^{\circ}$ toward the southwest. These measurements support shipboard and FMS interpretations of a tectonic dip to the Jurassic strata, and of an angular unconformity between the Oxfordian and Callovian (Shipboard Scientific Party, 1990).

\section{SUMMARY}

Site 801 represents the only penetration of Jurassic sediments in the Pacific Basin. FMS resistivity imagery of Hole 801B enables an enhanced stratigraphic column to be compiled, thereby augmenting the very poor recovery of the cored intervals. Lithologic interpretation of the various features observed in the FMS imagery is based upon the corresponding recovery of radiolarites and other facies in the corresponding cores. Identification of the importance of Callovian slumps above the basement, of various discontinuities in facies with associated suspected hiatuses, and of bedded chert within the upper Tithonian would not have been possible without these detailed FMS images. The FMS interpretations, supplemented by other logging tools, enable a detailed picture to be made of the variations in clay content and silicification within the Jurassic and Lower Cretaceous section.

\section{ACKNOWLEDGMENTS}

We thank the Ocean Drilling Program for inviting our participation on Leg 129, the Borehole Group at Lamont-Doherty Geological Observatory for encouraging innovative use of geophysical logs and providing computer and financial support (A.J.M.) and analysis software, Schlumberger (Ltd.) for supplying log-interpretation handbooks, the Engineering School of Purdue for access to color workstations, and the U.S. Science Advisory Committee and the Joint Oceanographic Institutions for providing financial support (J.G.O.). This paper was greatly improved by reviews and discussions from Cedric Griffiths, Mike Lovell, and Edward Winterer.

\section{REFERENCES}

Adams, J., Bourke, L., and Buck, S., 1990. Integrating Formation MicroScanner images and cores. Oilfield Rev., 2:52-66.

Anxionnaz, H., Delfiner,P., and Delhomme, J. P., 1989. Computer-generated corelike descriptions from open-hole logs. AAPG Bull., 74:375-393.

Bateman, R. M., 1985. Log Quality Control: Int. Human Resour. Dev. Corp., 291-300

Bourke, L., Delfiner, P., Fett., T., Grace, M., Luthi, S., Serra, O., and Standen, E., 1989. Using Formation MicroScanner images. Tech. Rev., 37:16-40.

Burke, J. A., Curtis, M. R., and Cox, J. T., 1967. Computer processing of log data enables better production in Cahveroo field. J. Pet. Tech., 19:889-895.

Dawnson-Grove, G. E., and Palmer, K. R., 1968. A practical approach to analysis of logs by computer. Trans. 2nd Formation Evaluation Symp., Can. Well Log. Soc., 112.

Ekstrom, M. P., Dahan, C. A., Chen, M. Y., Lloyd, P. M., and Rossi, D. J., 1986. Formation imaging with microelectrical scanning arrays. 27th Annu. Log. Symp. Trans., Soc. Prof. Well Log Analysts, Pap. BB.

Harker, S. D., McGann, G. J., Bourke, L. T., and Adams, J. T., 1990. Methodology of Formation MicroScanner image interpretation in Claymore and Scapa Fields (North Sea). In Hurset, A., Lovell, M. A., and Morton, A. C. (Eds.), Geological Applications of Wireline Logs. Geol. Soc. Spec. Publ. London, 48:11-25. 
Höcker, C., Eastwood, K. M., Herweijer, J. C., and Adams, J. T., 1990. Use of Dipmeter data in clastic sedimentological studies. AAPG Bull., 74:105-118.

Lancelot, Y., Larson, R. L., et al., 1990. Proc. ODP, Init. Repts., 129: College Station, TX (Ocean Drilling Program).

Lloyd,P.M., Dahan, C., and Hutin, R., 1986. Formation imaging with micro electrical scanning arrays. Anew generation of stratigraphic high resolution dipmeter tool. Trans. SPWLA 10th European Formation Evaluation Symp., Pap. L.

Pezard, P. A., Lovell, M., and Ocean Drilling Program Leg 126 Shipboard Scientific Party, 1990. Downhole images - electrical scanning reveals the nature of subsurface oceanic crust. Eos, 71:710.

Pezard, P. A., and Luthi, S. M., 1988. Borehole electrical images in the basement of the Cajon Pass Scientific Drillhole, California; fracture identification and tectonic implications. Geophys. Res. Lett., 15:1017-1020.

Savre, W. C., 1963. Determination of a more accurate porosity and mineral composition in complex lithologies with the use of the sonic, neutron and density surveys. J. Pet. Tech., 15:945-959.

Schlumberger, 1981. Dipmeter Interpretation, Volume I-Fundamentals: New York (Schlumberger).

Schlumberger, 1983. Stratigraphic High Resolution Dipmeter Tool, document M-086300: Paris (Schlumberger).

Schlumberger (Ltd.), 1986. Dipmeter Interpretation-Fundamentals, document SMP-7002: Paris (Schlumberger).

Serra, O., 1989. Formation MicroScanner Image Interpretation: Houston (Schlumberger Educational Services).

Shipboard Scientific Party, 1990. Site 801. In Lancelot, Y., Larson, R. L., et al., Proc. ODP, Init. Repts., 129: College Station, TX (Ocean Drilling Program), 91-170.

\section{Date of initial receipt: 28 May 1991 \\ Date of acceptance: 10 February 1992 \\ Ms 129B-146}

\section{APPENDIX}

\section{Processing of Formation MicroScanner Resistivity Logs}

\section{Schlumberger Processing and Image Presentation}

Conductivity changes of the formation as measured by the electrode arrays of the Formation MicroScanner are converted by Schlumberger (Ltd.) into a gray scale to produce a black/white image of the borehole (Lloyd et al., 1986; Serra, 1989). This imagery procedure incorporates a series of processing steps.

1. During logging, the sensitivity of the electrodes on the pads is dynamically varied to optimize their operating range, even under conditions of great resistivity contrasts. After creating mapped data files from the original FMS data onto tapes, a normalization is applied to the recorded resistivity curves for the effects of changing this sensitivity level. The normalization removes image distortion created during logging through formations of widely differing lithologies.

2. The individual curves are speed-corrected for the effects of irregular tool movements during logging. This correction, which is important for ODP logging operations at sea, is accomplished by estimating the instantaneous tool velocity using a recursive linear least-squares estimation algorithm, or Kalman filtering, to process measurements from the 3-axis accelerometer of the tool.

3. A horizontal equalization is made across all of the individual resistivity buttons in order to put the same dynamic range on each of the fast channels. This procedure removes any "vertical stripe" effect, which would result from individual buttons recording slightly different absolute levels in resistivity.

4. A variable density raster image is produced which represents changes in formation resistivity - formations having higher resistivity appear whiter on the black-white imagery.

5. There is also an option for a moving-window image enhancement to be made to highlight features. This HILITE-enhancement is made by normalizing the signal to remove the low-frequency content of the grey levels, thereby increasing the contrast in adjacent resistivity levels. Such movingwindow enhancements are used to accentuate small-scale features, while suppressing larger trends.

6. The final raster images are displayed on a plotter device, such as a BENSON B90 or a VERSATEC V80. The plot can be either in a straight mode, which puts the first points of all image lines on the same vertical axis, or in an azimuthal mode, which positions each line of the image based on the azimuth of the first pad.

For each 36-m section of FMS data recorded in Hole 801B, the displayed image was contrast-adjusted, such that a 16-gray scale was used from the highest to lowest resistivity values-maximum resistivity was set to white and minimum resistivity to black, respectively - within that interval. This processing brings out details within an otherwise thick "gray" formation, but causes two artifacts. First, a "border-discontinuity" between successive sections is created by the different gray scales used by those sections; therefore, the same lithology can appear light gray in one section and dark gray in the adjacent one. Second, there is possible loss of detail if spurious ultra-high or ultra-low resistivity measurements are contained within the data file, thereby causing the majority of the other readings to fall in a narrow gray range. This contrast loss was noted for an early processed version of the lowest interval (Callovian) of Hole 801B due to a basal "solid-black" zone of zero-resistivity (or null measurements by the tool).

Within each of these 36-m contrast-adjusted sections, the same degree of resistivity, hence the same degree of silicification, will be displayed as the same grayness value on the imagery. Chert-rich and clay-rich sediment intervals can be identified and compared. But comparisons can be reliably made between successive contrast-adjusted sections only if the "border-contact" of these sections, which is presumably of very similar lithology, does not display a major contrast difference-this was the case for most of our adjacent sections. Otherwise, one must "re-calibrate" one's eye for the new lithologygrayness correspondence.

Schlumberger provides an FMS image examiner workstation for interactive interpretation (Serra, 1989). This workstation is to provide users with a system for in-depth interpretation of borehole imagery. Unfortunately, this workstation was not available at the Borehole Research Group due to the cost of such hardware and software materials. Also, some scientific applications, which require new image processing techniques, were not yet available on this Schlumberger workstation. Therefore, we created another package, the "FMacS" project, for use in FMS interpretation using a Macintosh workstation.

\section{Formation MicroScanner Imagery on Macintosh II Color Workstation}

Image analysis by computer has been used by geologists for many years, but only recently has it become readily affordable. We describe here a program "FMacS" to convert resistivity data coded in logging "LIS" format to 8-bit raster image files, then present some of the geological applications using free-domain image-processing software on the Macintosh II applied to such image files.

The FMacS software has been written on a DEC MicroVax in FORTRAN 77. The program reads special FMS field edit tapes containing 67 channels in a special order after speed-correction and normalization. In the LIS format, a hierarchy is used for storing and retrieving data (Bateman, 1985). This hierarchy separates physical representation from logical information interpretation. Each magnetic tape is kept logically complete by recording on each tape the information required to interpret the data on that tape. The LIS format has two structures: logical and physical. Logical structure refers to the type of information and the organization of the information; physical structure refers to the physical dimensions of the information or how much space it occupies. Then the FMacS program converts relative resistivity data into a 256 -gray-level range over a 30 -ft (about $9 \mathrm{~m}$ ) window and creates for each of these windows an oriented, 8-bit raster image file. The $30-\mathrm{ft}$ window size is according to the memory capacity of a standard Macintosh II. Once images have been created, they are transferred from the MicroVax to the Macintosh II using tapes or communication software, and are converted to tag image file format (TIFF). TIFF is a common document format for the Macintosh in which the resolution and the range of grays of the image are stored. Therefore, these images can be processed or visualized using most of the image software and free-domain image-processing software for the Macintosh II.

With the data in the form of a digital image, we are able to utilize several image processing operations to improve the overall quality of the imagery. Other processing is possible; for example, application of histogram distribution on selected intervals to separate different degrees of silicification, as was presented in a section of this paper. In addition, the digital images allow a better recognition of fine lithology details.

In the future, possible scientific applications of the FMS images in Ocean Drilling Program holes may include detailed correlation of coring and logging depths, orientation of cores, mapping of fractures, faults, foliations, and formation structures, and the analysis of depositional environments. The later application requires information on transport direction, structure of pore space, nature of contacts, and identification of depositional sequences (e.g., Adams et al., 1989; Anxionnaz et al., 1990). 


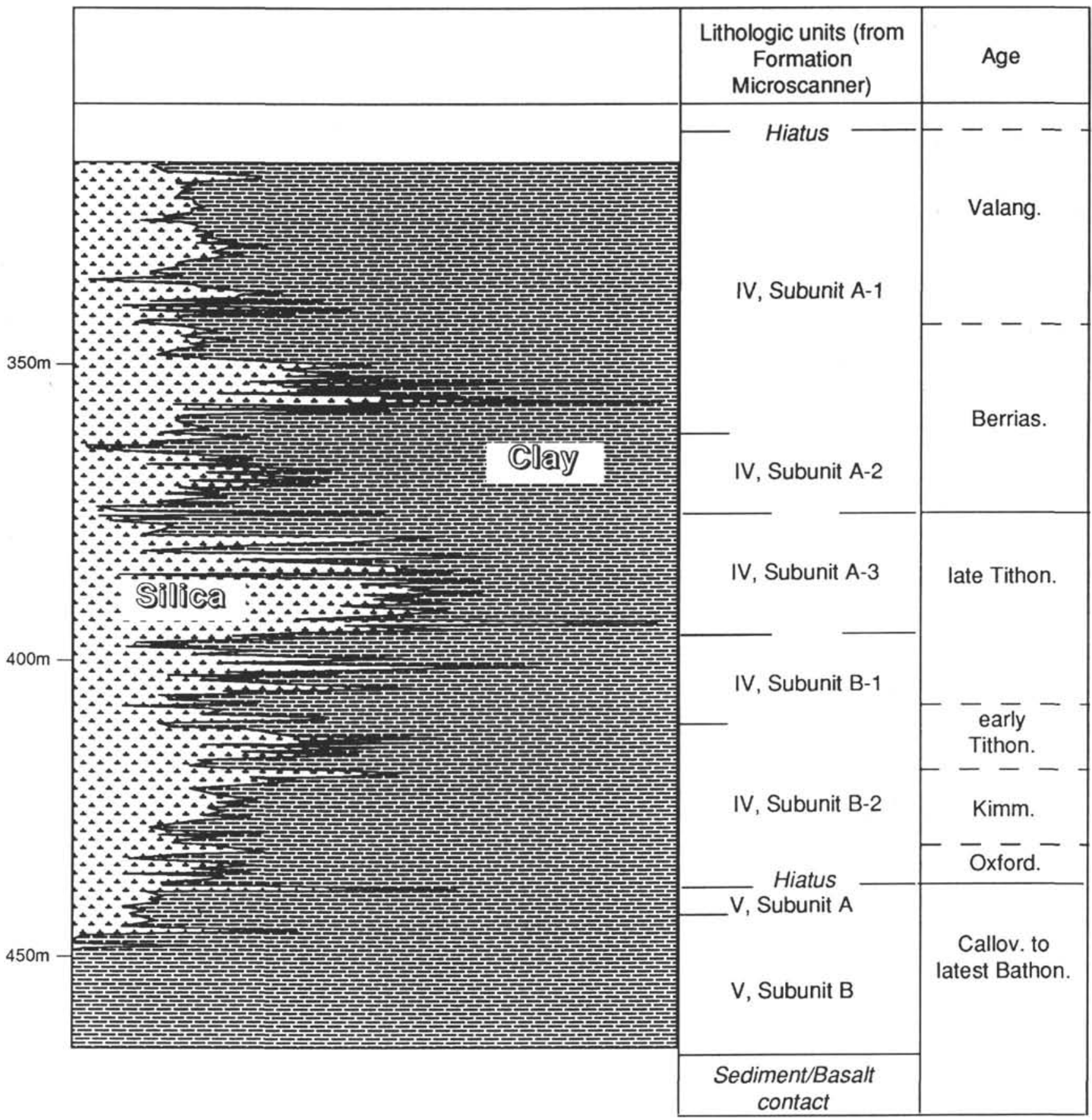

Figure 14. Degree of silicification of Jurassic and Lower Cretaceous radiolarites of Site 801. Ratio of clay-rich to chert-rich is computed from calibrated response of density and sonic velocity logs. A general trend of increasing silicification characterizes the Jurassic, from clay-rich Callovian (lowest portion of Unit VB was not logged) through bedded-chert facies of upper Tithonian. The Lower Cretaceous is relatively clay-rich, with a peak in silification in the lower portion of Lithologic Subunit IVA-1. 


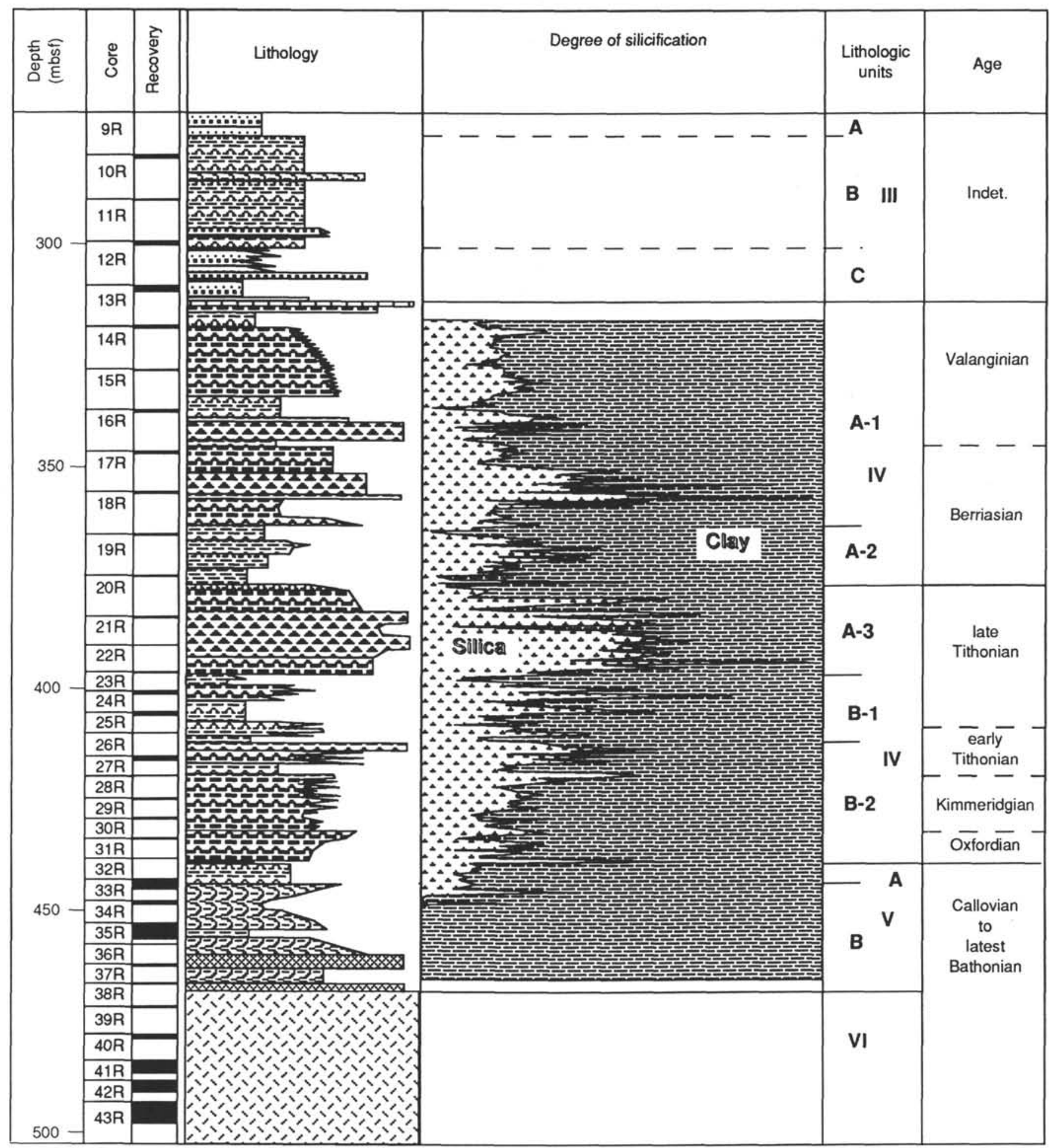

Figure 15. Integrated stratigraphy for the Jurassic and Lower Cretaceous of Site 801. Lithology column and corresponding lithostratigraphic subunits are based upon the FMS imagery and recovered sediments (Fig. 2), degree of silification is a semiquantitative calibration of the density and sonic velocity logs (Fig. 8), and biostratigraphy is from the shipboard paleontology (Shipboard Scientific Party, 1990). 